\title{
MORPHOLOGICAL CHARACTERISTICS AND DISTRIBUTION OF DOLINES IN SLOVENIA, A STUDY OF A LIDAR-BASED DOLINE MAP OF SLOVENIA
}

\author{
MORFOLOŠKE ZNAČILNOSTI IN PORAZDELITEV VRTAČ V \\ SLOVENIJI, ŠTUDIJA VRTAČ NA OSNOVI \\ LIDARSKIH PODATKOV
}

\author{
Andrej MIHEVC', Rok MIHEVC ${ }^{2, *}$
}

\begin{abstract}
UDC 551.435.82:528.8.044.6(497.4)

Andrej Mihevc \& Rok Mihevc: Morphological characteristics and distribution of dolines in Slovenia, a study of a lidarbased doline map of Slovenia

Dolines are small to intermediate enclosed depressions and are the most numerous karst feature in Slovenia. They are circular in plan form and vary in diameter from a few metres to over a kilometre. They are developed in limestone, dolomite, carbonate breccia and conglomerate and occupy different geomorphic settings. They were formed by various processes like dissolution, collapse, suffosion and transformation of caves to surface features by denudation. Publicly accessible lidar data, provided by a nationwide laser scanning project of Slovenia, was used for this study. To catalogue the dolines, we manually label a fraction of the digital elevation model (DEM) with a binary mask indicating if the area is a doline or not. We then train a slightly modified u-net, a type of machine learning algorithm, on the labelled territory. Using the trained algorithm, we infer the binary mask on the entire DEM. We convert the resulting mask into an ESRI Shapefile and manually verify the results. We note that the training and inference are error prone on types of relief that were less common in the training set (e.g., the relatively uncommon collapse dolines). We believe manual verification mitigates most of these errors, so the resulting map is a good basis for the doline study. We have made our georeferenced catalogue of dolines available at https://dolines.org/ (Mihevc \& Mihevc 2021). Dolines are found in most of the karst areas, except mountains where they were eroded by glacial action or covered by glacial deposits. We detected 471,192 dolines and divided them into three genetic types. Most abundant are solution dolines $(470,325)$. The average doline is $9 \mathrm{~m}$ deep, has a diameter of $42 \mathrm{~m}$ and a volume of $14,098 \mathrm{~m}^{3}$. The density of dolines on levelled surfaces can be as high as $500 /$ per $\mathrm{km}^{2}$. They are
\end{abstract}

Izvleček

UDK 551.435.82:528.8.044.6(497.4) Andrej Mihevc \& Rok Mihevc: Morfološke značilnosti in porazdelitev vrtač $v$ Sloveniji, študija vrtač na osnovi lidarskih podatkov

Vrtače so majhne do srednje velike zaprte depresije in so najštevilčnejša kraška oblika v Sloveniji. So krožne oblike in imajo premer od nekaj metrov do več kot kilometer. Nastanejo na apnencu, dolomitu, karbonatni breči in konglomeratu. Nastanejo $\mathrm{v}$ različnih geomorfnih okoljih, in to $\mathrm{z}$ različnimi procesi, kot so raztapljanje, grezanje, sufozija in pretvorba jam v površinske oblike $\mathrm{z}$ denudacijo. Za to študijo so bili uporabljeni javno dostopni lidarski podatki, ki so bili zajeti s skeniranjem celotnega ozemlja Slovenije. Za katalogiziranje vrtač del digitalnega modela višin ročno označimo z binarno masko, ki označuje, ali je območje vrtača ali ne. Nato na označenem ozemlju učimo algoritem globokega strojnega učenja u-net. Z algoritmom napovemo binarno masko na celotnem ozemlju Slovenije. Nastalo masko pretvorimo $\mathrm{v}$ format SRI Shapefile in ročno preverimo rezultate. Pri delu smo ugotovili, da so napake strojnega učenja in napovedovanja binarne maske večja pri tistih vrstah vrtač, ki so bile manj pogoste $\mathrm{v}$ učnih podatkih (npr. pri razmeroma redkih udornih vrtačah). Menimo, da smo z ročnim preverjanjem odpravili večino napak, zato je dobljeni katalog vrtač dobro izhodišče za nadaljnjo študijo. Georeferencirani katalog vrtač je dostopen na spletnem naslovu https://dolines.org/. Vrtače zasedajo večino kraških območij, razen planot, kjer so bile zaradi ledeniškega delovanja erodirane ali prekrite $\mathrm{z}$ ledeniškimi nanosi. Odkrili smo 471.192 vrtač in jih razvrstili v tri tipe glede na njihov izvor. Najpogostejše so korozijske vrtače (470.325 primerkov). Povprečna vrtača je globoka $9 \mathrm{~m}$, ima premer $42 \mathrm{~m}$ in prostornino $14.098 \mathrm{~m}^{3}$. Gostota vrtač na uravnanih površinah je lahko tudi do 500/ vrtač na $\mathrm{km}^{2}$. Vrtač ni na dnu polj in na strmih pobočjih, manj jih je na nagnjenih površinah. Dolo-

\footnotetext{
${ }^{1}$ Karst Research Institute ZRC SAZU, Titov trg 2, SI-6230 Postojna, Slovenia, e-mail: andrej.mihevc@zrc-sazu.si

${ }^{2}$ Datatart B.V., Tweede Jacob van Campenstraat 133D, NL-1073XR, Amsterdam, rok.mihevc@gmail.com

* Corresponding author
} 
absent from the floors of poljes and steeper slopes, and are less abundant on sloping surfaces. We have identified 314 dolines to be of collapse origin. The mean depth of collapse dolines is 49 $\mathrm{m}$, and 20 of them are deeper than $100 \mathrm{~m}$. The mean volume is 1.2 million $\mathrm{m}^{3}$, with the largest having a volume of 11.6 million $\mathrm{m}^{3}$. Most of the collapse dolines can be found close to ponors or springs or corridors where large underground rivers flow. We have detected 553 suffosion dolines formed by suffosion of sediments in blind valleys or on poljes. This basic data set for dolines enables further study and comparison of dolines with the geology and topography of the karst.

Key words: Dolines, Slovenia, lidar, number of dolines, type of dolines, size of dolines, machine learning, catalogue of dolines. čili smo 314 udornih vrtač. Povprečna globina udornih vrtač je $49 \mathrm{~m}, 20$ pa jih je globljih od $100 \mathrm{~m}$. Povprečna prostornina je 1,2 milijona $\mathrm{m}^{3}$, največja pa ima prostornino 11,6 milijona $\mathrm{m}^{3}$. Večina udornih vrtač je blizu ponorov, izvirov ali tokov velikih podzemnih rek. Odkrili smo še 553 sufozijskih vrtač, ki so nastale s spiranjem sedimentov v slepih dolinah ali na poljih. Narejeni katalog vrtač omogoča nadaljnje proučevanje in primerjavo vrtač z geologijo in topografijo krasa.

Ključne besede: vrtače, Slovenija, lidar, število vrtač, tip vrtač, velikost vrtač, strojno učenje, katalog vrtač.

\section{INTRODUCTION}

Dolines are surface depression relief forms and the most common relief form in Slovenia. They form in places where dissolution and transport through karst are locally increased. In the past, unusual phenomena such as caves, springs and sinkholes of rivers, and intermittent flooding of poljes attracted the most attention in karst research. The doline became the subject of research only in the middle of the $19^{\text {th }}$ century, when researchers became interested in karst denudation, the formation of red soils, and the formation of the karst surface in general.

Some karst researchers in Slovenia, especially speleologists, initially attributed the doline to collapse genesis assuming dolines formed from underground cavities. Large collapse dolines in the Ljubljanica catchment and those above the underground flow of the Reka river have been cited as examples (Schmidl 1854; Kraus 1887; Putick 1889). Others considered the doline to be a surface relief form and argued that dolines form in places of slightly faster corrosion (Cvijić 1893). The debate over dolines was ongoing until the end of the $19^{\text {th }}$ century, but it seems to have been largely due to a poorly defined subject of discussion.

At the turn of the $20^{\text {th }}$ century, dolines were discussed as part of a cyclic theory of geomorphological surface development (Grund 1914). It was assumed that dolines were an intermediate form in a longer process and were supposed to change over time and/or merge into larger relief forms such as uvalas. Dolines were also considered to be indicative forms of karst (Sweeting 1973).

Classification of dolines by morphogenetic and morphographic setting was established in the $20^{\text {th }}$ century. Morphogenetically, they are classified into solution dolines, which are the most frequent, collapse, dropdown and suffosion dolines (Ford \& Williams 1989). Shapewise morphographical division into funnel, kettle shape, etc. was proposed and is in general use now (Cramer 1941; Šušteršič 1984; Gams 2003; Frelih 2014).

While the mechanisms that form suffosion and collapse dolines have been explained, no wide consensus has been achieved regarding the mechanisms forming solution dolines (Stepišnik 2015). The most common ex-

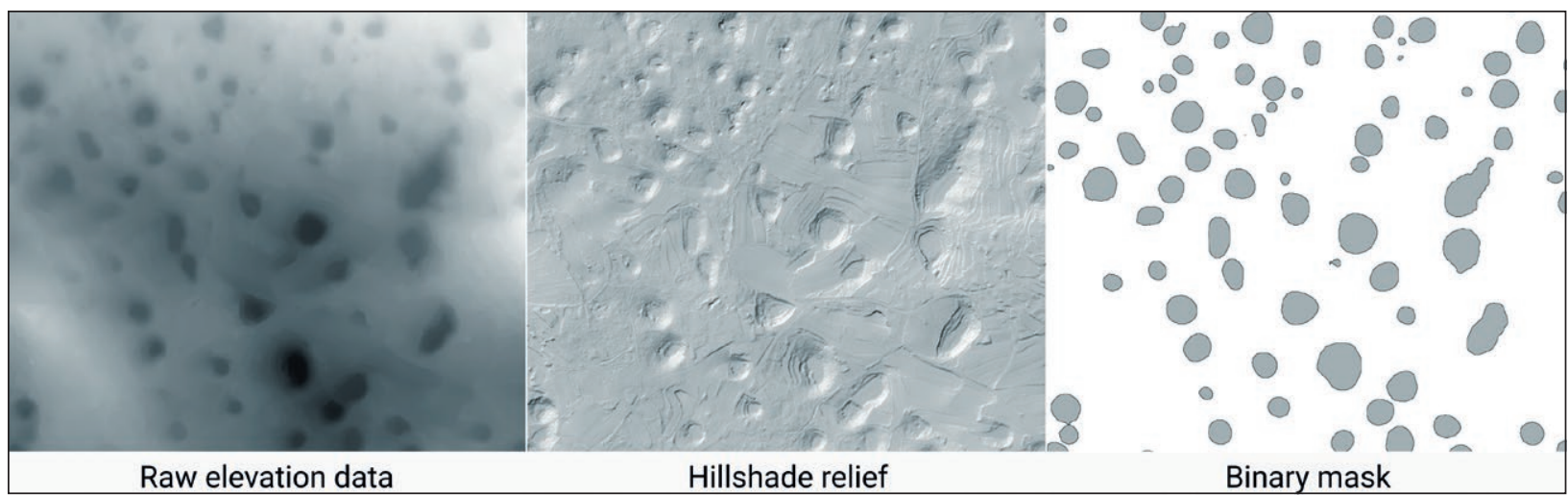

Fig. 1: Example of the image data used for mapping dolines. Hillshade relief was applied to the raw elevation data and then used to manually draw binary masks. 
planation assumes locally enhanced vertical flow as the driver of solution doline growth. Some authors propose that enhanced flow can be a consequence of local structure, such as fractures (Čar 2001) or shafts (Šušteršič 1994). However, there has been little research into explaining solution dolines as surface forms shaped by various factors such as organic carbon dioxide production in the soil, climate, formation of depression and feedback mechanisms (Bárány-Kevei 1998; Zambo 1997). Rather, research has tended to focus on land use and the anthropogenic transformation of dolines.

Even less attention has been paid to the territorial distribution of dolines, their density, the relative area of the surface they occupy, and their distribution concerning age, type, and slope of the surface. This was relatively difficult to do in the past as there was no accurate surface or doline map nor the computing power to process and interpret the data (Grlj 2020). After national aerial laser scanning of Slovenia was completed in 2015, the resulting lidar data enabled an accurate cartographic representation of the shapes and distributions of dolines as well as the possibility of data driven analysis. This development enabled our study of all of the dolines in Slovenia and we present our results and conclusions below.

\section{METHODS}

Our goal was to first catalogue all Slovenian dolines to enable our analysis. As manual labelling would require work hours we did not have available, we decided to apply machine learning for this task.

We used the lidar data provided by the national aerial laser scanning of Slovenia, a project which covered the entire territory of Slovenia and was conducted during the period between 2011 and 2015 (Triglav Čekada et al. 2015). We also included a small part of the Karst plateau that lies beyond the state border in Italy, scanned by Civil Protection of Friuli Venezia Giulia during the period of 2006-2010 (FVH 2021).

U-net convolutional neural network, primarily developed for image segmentation, was used in processing our image data (Ronneberger et al. 2015). To do so, we manually labelled a fraction of the digital elevation model (DEM) of Slovenia with a binary mask, mapping which parts of the territory are dolines (Fig. 1). Our binary mask was a raster grid of geocoded $1 \mathrm{~m}^{2}$ pixels covering the territory of Slovenia. The pixel value indicates whether we consider the location a doline or not. We trained a u-net with elevation as input and binary mask as the output. We then applied the trained network to infer a binary mask on a larger area and manually corrected segmentation errors to produce a new training dataset. The original training dataset and the newly produced one were joined and used to train a better u-net model. We repeated this infer-correct cycle for several steps until we produced a validated training set of about $1000 \mathrm{~km}^{2}$. We then trained the final $\mathrm{u}$-net model on this dataset and inferred the mask over the entire territory of Slovenia. We note that the training and inference are error prone on types of relief that were less common in the training set (e.g., the relatively uncommon collapse dolines). By manual verification we have cleared most of these errors, so the resulting map is a good basis for the study of dolines.

A binary mask is not sufficient to study individual dolines as dolines are not inferred as separate entities, and partly merging dolines are often labelled as a single continuous area. To correct this, we split the inferred areas of the binary mask by computing an image in which the pixel's values represent the distance to the edge of the mask. The resulting gradient raster is then segmented with a topological watershed algorithm. We convert the resulting binary mask areas into geocoded polygons that represent the circumferences of dolines.

To estimate labelling error, we randomly selected 30 $\mathrm{km}^{2}$ out of $7712 \mathrm{~km}^{2}$ that contain dolines, created hillshade renders of them and manually labelled dolines in them. We used this area to evaluate our machine produced results. It should be noted that manual labelling is not perfect because human labellers can misread the hillshaded relief or misinterpret surface features. The definition of the doline area itself is not well defined, which we aim to correct with this work.

To quantify the segmentation quality, we compare the set of actual doline areas A with the set of the inferred doline areas B. We quantify it with Jaccard index (Eq. 1)

$$
J(A, B)=\frac{|A \cap B|}{|A \cup B|}
$$

and Sørensen-Dice coefficient (Eq. 2)

$$
D(A, B)=\frac{2|A \cap B|}{|A|+|B|} .
$$

The measured Jaccard index on this set was 0.604 and the Sørensen-Dice coefficient was 0.725. We find this a relatively good segmentation result. 


\section{RESULTS AND DISCUSSION}

\section{NUMBER OF DOLINES, TYPE AND DISTRIBUTION}

With the use of the selected algorithm, we marked 471,192 dolines across all of the Slovenian karst areas, which represent $9530 \mathrm{~km}^{2}$ (Gostinčar 2016) of the total surface. In terms of the number of dolines segmented and the area covered, we obtained the following results which are presented in Tab. 1 and Fig. 2.
Tab. 1: A comparison between manual and machine evaluation of selected areas.

\begin{tabular}{|l|c|c|c|}
\hline & $\begin{array}{c}\text { Manual } \\
\text { set }\end{array}$ & $\begin{array}{c}\text { Machine } \\
\text { predicted }\end{array}$ & Difference \\
\hline Number of dolines & 4335 & 3645 & $15.9 \%$ \\
\hline Doline area & $6.65 \mathrm{~km}^{2}$ & $7.35 \mathrm{~km}^{2}$ & $16.1 \%$ \\
\hline
\end{tabular}

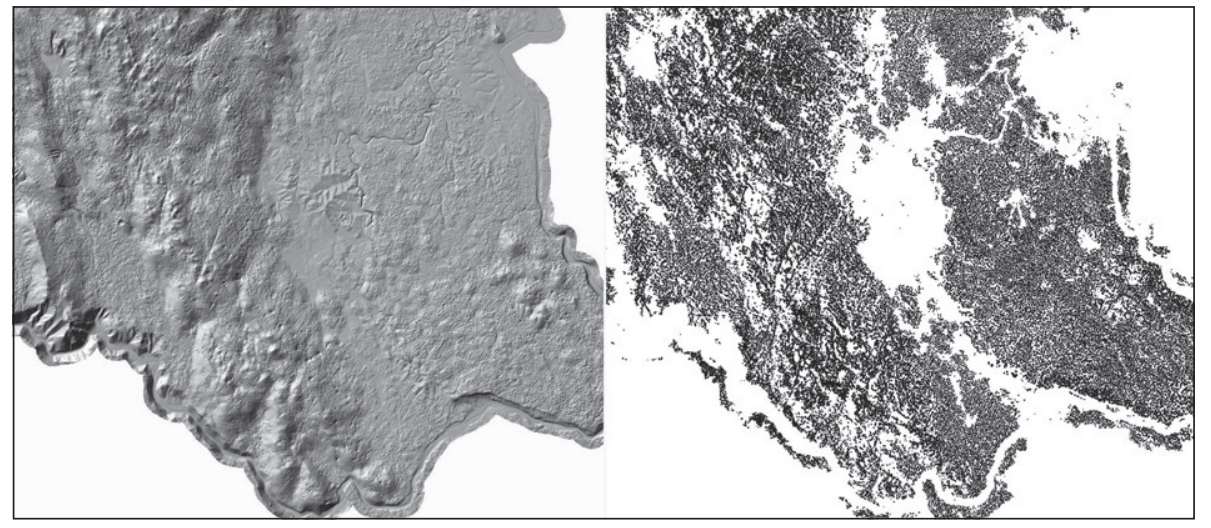

Fig. 2: Part of the machine labelled territory. Hillshade relief on the left, doline binary mask on the right.

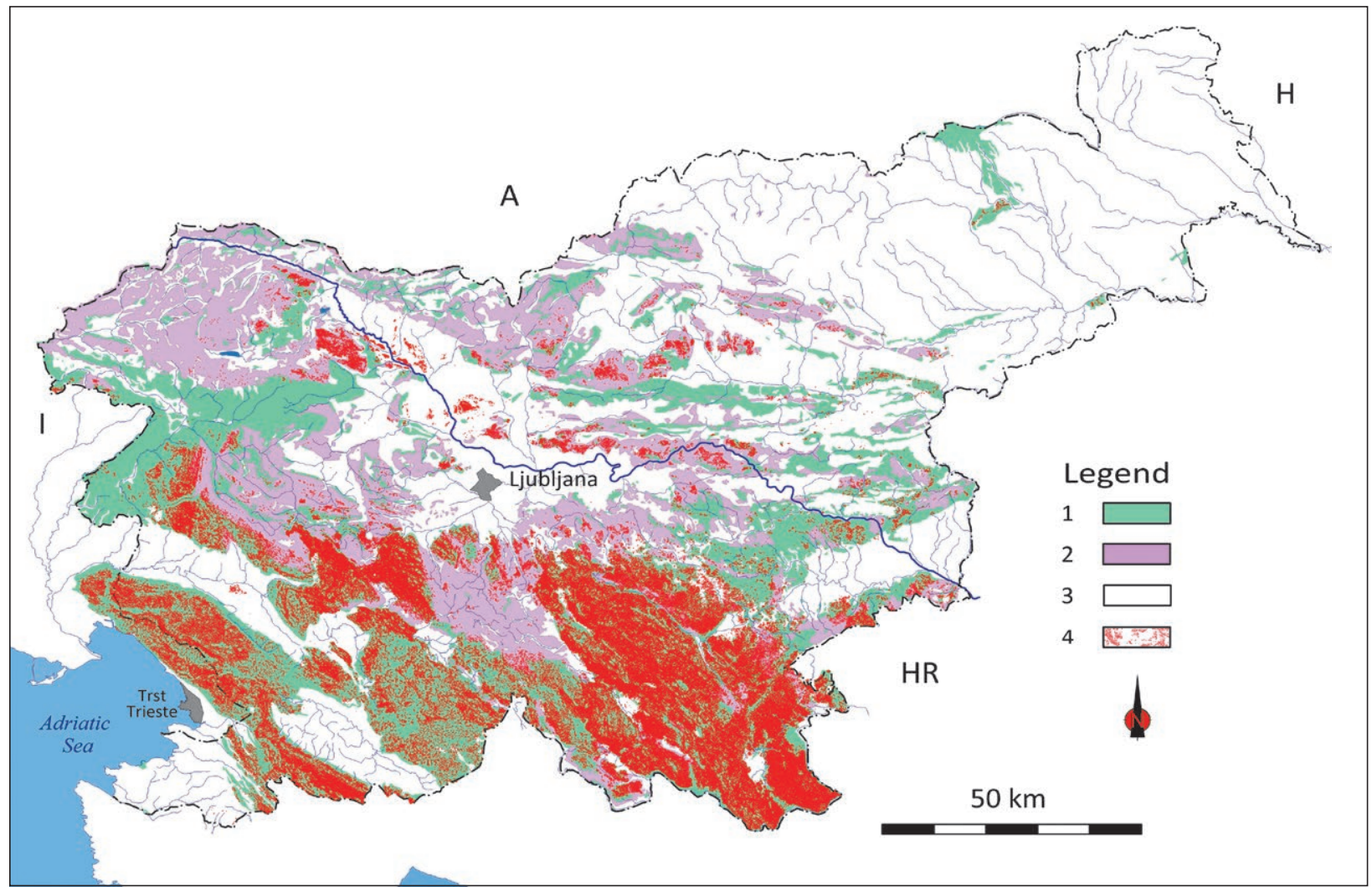

Fig. 3: Distribution of dolines in different carbonate rocks in Slovenia defined by lidar datasets and machine learning (Gostinčar 2016). Legend: 1 limestone, 2 dolomite, 3 non-carbonate rock, Pleistocene carbonate gravel, 4 positions of individual dolines are marked with red dots. 
We believe the number of machine labelled dolines was low due to some doline pairs being incorrectly segmented as one doline instead of two or more. It also appears that our u-net model erred on the side of labelling an individual doline area smaller than in reality. We are satisfied with this result, but we feel it could be further improved. We provide the resulting dataset online for further study (Mihevc \& Mihevc 2021).

Dolines develop on all types of exposed carbonate rocks, but the density of dolines and their spatial distribution vary significantly (see Fig. 3). Doline density closely matches the general division of Slovenia into three karst provinces, the Alpine, Isolated karst and Dinaric karst (Gams 1974). These areas are defined according to the general morphological and hydrological characteristics and their evolutionary history (Habič 1969).

We classified dolines by their genesis into solution dolines, suffosion dolines, and collapse dolines. We use our knowledge of the terrain to classify the labelled dolines.

Most abundant are solution dolines (470,325 classified and detected). The necessary condition for their formation is karstified bedrock, which allows vertical drainage of infiltrated water. They form in locations where local corrosion is slightly higher than in the neighbouring surface. The shapes formed in this way have one lowest point and slopes that converge towards that point. The formation of the doline causes slope processes that result in negative feedback, which inhibits the bottom deepening, while positive feedback, e.g., accumulation of soil, moisture, and $\mathrm{CO}_{2}$, encourages deepening.

The slopes of the solution dolines are mostly without continuous soil cover, often rocky, and have a layer of colluvial soil at the bottom. Most solution dolines are stable features that have already reached an equilibrium shape. Equilibrium state depends on the local conditions - rock, climate, etc. Solution dolines in an equilibrium state are part of the surface and descend along with it.

Small collapse dolines, which form when surface denudation reaches underground cavities and their ceiling collapses, were not separated from ordinary solution dolines.

The average solution doline in Slovenia is $9 \mathrm{~m}$ deep, has a diameter of $42 \mathrm{~m}$, and a volume of 14,000 $\mathrm{m}^{3}$. The density of dolines on levelled surfaces can be higher than 500 per $\mathrm{km}^{2}$. They can take up as much as $80 \%$ of the surface.

Suffosion dolines (553 classified and detected) are formed by suffosion, or the downwashing of noncohesive sediments covering the karst surface into the underground. They usually form as vertical dolines with steep slopes in the sediment, which within a few years transform into funnel-shaped depressions. Sediments in karst were mostly deposited in blind valleys, poljes and as glacial till and periglacial deposits in the Alps. Most of the suffosion dolines are located in these environments.

Collapse dolines (314 classified and detected) are formed by the collapse of the ceiling of an underground cave creating a depression on the surface. Collapse dolines usually have steep or vertical slopes and screes below them. Collapse dolines are often close to the sinking points of surface streams (Mihevc 2011). If the hydrological conditions change, their growth is hindered and they become relict and develop more gentle slopes as a result. Literature (Ford \& Williams 1989) knows one term for this type of doline and that is the collapse doline. In this article, however, we use two terms in order to differentiate between features of significantly different genesis. These terms are collapsed cave and collapse doline.

The depression referred to as a collapsed cave occurs when the ceiling above the underground passages is thinned due to denudation. If the ceiling above the cave completely dissolves, an unroofed cave is formed. If the ceiling becomes unstable and collapses into the cavity below, the depression that is formed can be called a collapsed cave (Zupan Hajna et al. 2008). The depression formed on the surface is smaller than the original cavity. These depressions often have entrances to the remaining parts of the caves. The age and permanence of such phenomena depend on the rate of denudation. These collapsed caves degrade over time and are mostly very similar in size and shape to solution dolines. They are very common on karst. They are usually characterized by a bigger amount of clastic sediments not originated from nearby karst surfaces (Mihevc \& Zupan Hajna 1996). However, because they are difficult to distinguish from solution dolines, they are not discussed separately in this article.

The second type of depression which is referred to as a collapse doline is formed by the collapse of the ceiling over active caves where the tectonically deformed bedrock is simultaneously eroded and corroded by an underground water flow (Stepišnik 2010; Gabrovšek \& Stepišnik 2011). However, the doline is not the result of a simple rock failure but is rather a speleogenetic process causing concentrated undermining that occurs in tectonic zones that are dissected by subsurface with large fluctuations in water table level (Mihevc 2001). During floods, water is forced into fissures, and at the end of floods, water flows out and corrodes them. Thus, where the water flow crosses the epiphreatic zone, corrosion is not limited to the surface of the underground river passage, but the entire epiphreatic zone. This allows locally intensive bedrock removal and thus the formation of large underground chambers and/or large collapse dolines (Mihevc 2001; Gabrovšek \& Stepišnik 2011). Such a process lasts 
a long time and is simultaneous with the development of the surface and caves.

The mean depth of the collapse dolines counted in this paper is $49 \mathrm{~m}$, and 20 of them are deeper than 100 $\mathrm{m}$. The mean volume is 1.2 million $\mathrm{m}^{3}$, with the largest having volume of 11.6 million $\mathrm{m}^{3}$. Most of the collapse dolines can be found close to ponors or springs or in corridors where large underground rivers flow (see Fig. 22).
Here we present the characteristics and distribution of dolines and give examples from different parts of the karst surface in Slovenia (Fig. 6). We selected smaller characteristic karst areas with dolines of uniform shapes, distribution and density. For the selected areas, we determined the number of dolines per $\mathrm{km}^{2}$ and the proportion of the area occupied by the dolines. Selected surfaces were graphically represented with a DEM made based on

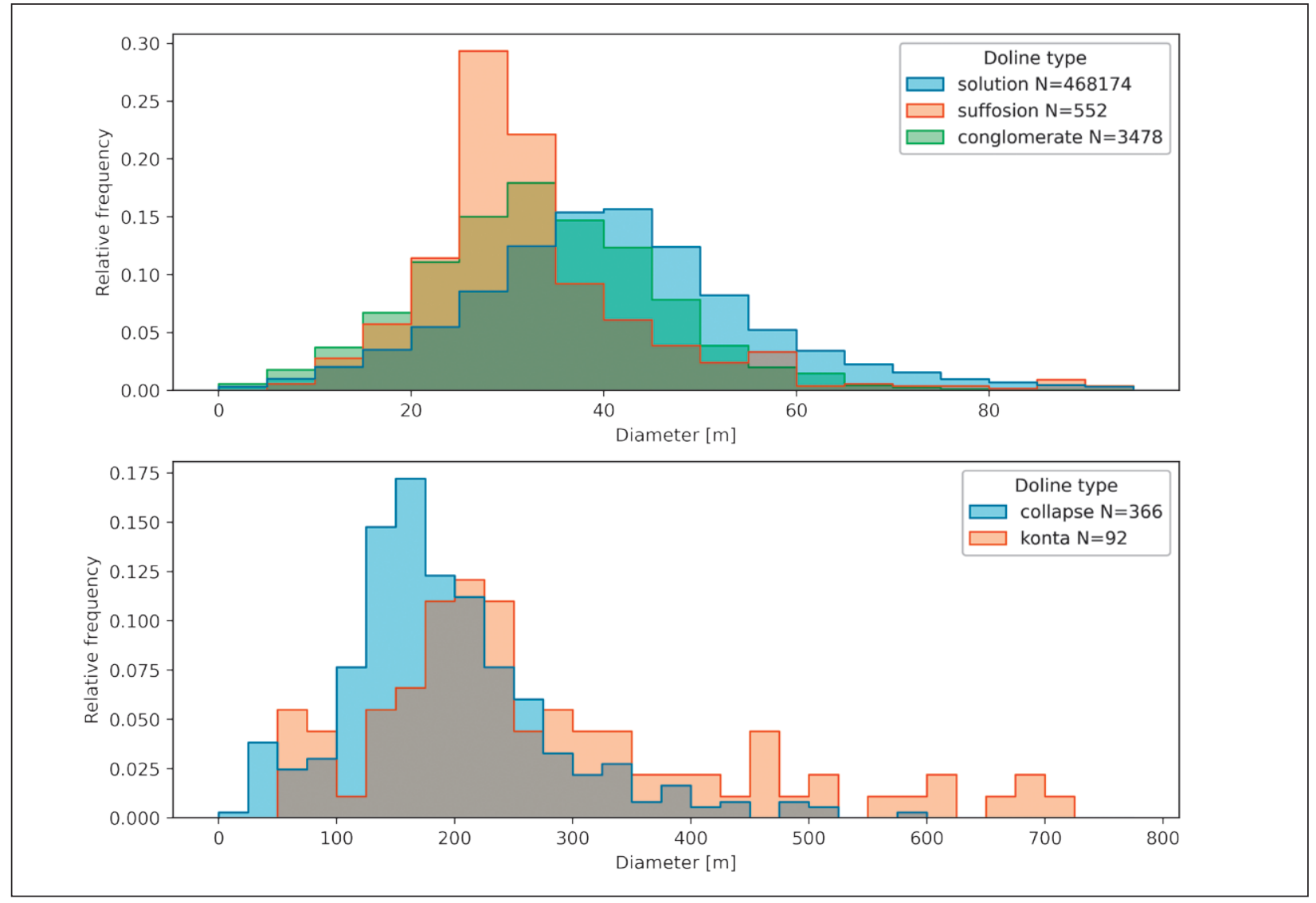

Fig. 4: Histogram of doline diameters.

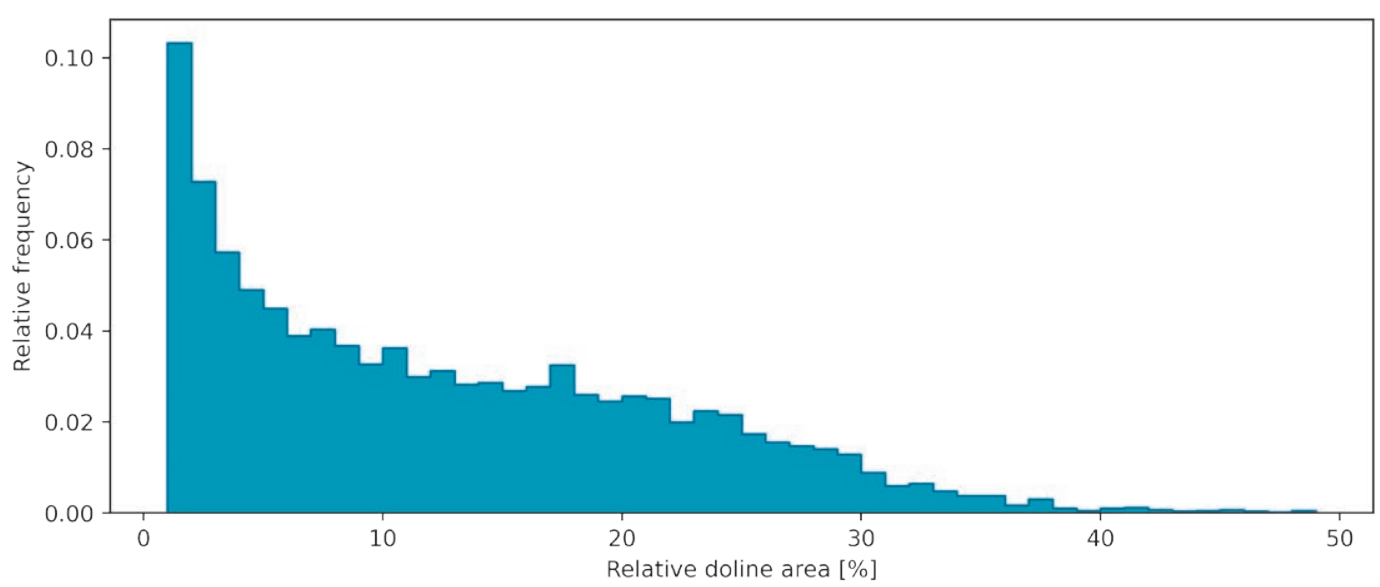

Fig. 5: Histogram of relative doline area. Fraction of territory below $1 \%$ is omitted for readability. 
lidar data of the Republic of Slovenia with a $1 \mathrm{~m}^{2}$ grid using hillshading and described according to geological, geomorphological and hydrological characteristics. We try to define the present dolines in terms of age and genetic conditions. The geology of the selected study areas is described based on the Basic Geological Map of Slovenia 1:100,000 (https://ogk100.geo-zs.si/).

\section{DOLINES OF THE ALPINE KARST}

Alpine karst developed in the Julian Alps and KamnikSavinja Alps, both part of the Southern Calcareous Alps. The karst is developed mostly in Triassic limestones and dolomites. The initial post-Oligocene planation surface was exposed to post-Miocene uplift. This caused deep incision of river valleys separating old surface into mountain groups and plateaus (Mihevc et al. 2013; Häuselmann et al. 2015a, b). Most of the former surface was transformed into slopes, and only smaller parts of the levelled surface are preserved as high karst plateaus.

The Alps have high precipitation (1600 to $3200 \mathrm{~mm}$ ) and long and thick snow cover. Karst is characterised by a thick vadose zone developed with thousands of accessible caves, several deeper than $1000 \mathrm{~m}$. Alpine karst aquifers discharge in numerous karst springs that are located at the floors of surrounding fluvial valleys or basins.

In the Pleistocene, the Alps were glaciated with plateau and valley glaciers. Glacial equilibrium line altitude was between 1200 and $1300 \mathrm{~m}$ (Žebre et al. 2016), but valley glaciers descended to below $200 \mathrm{~m}$ in the Western part and $500 \mathrm{~m}$ in the central part of Slovenia. In glaciated plateaus, dolines and smaller karst features that were formed before the last glacial cycle were eroded by glacial action or covered by glacial deposits. The highest positioned dolines are preserved at altitudes around $1600 \mathrm{~m}$ on small levelled surfaces that were not glaciated. The highest density of dolines in the Alps is found on the high karst plateaus of Mežakla, Pokljuka and Jelovica.

In the Alpine karst, solution dolines are the most common. There are no collapse dolines, only suffosion

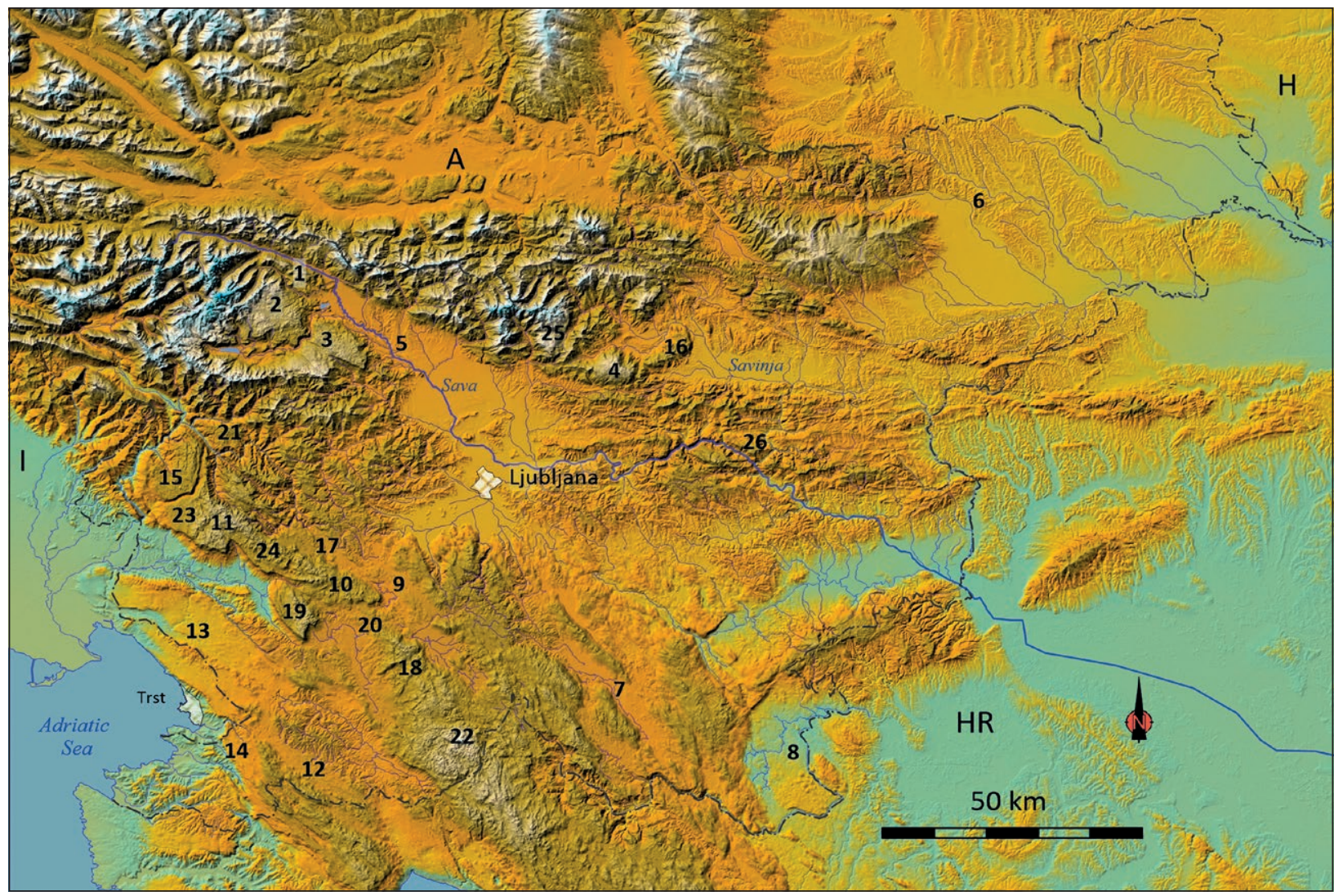

Fig. 6: Studied and described karst areas of Slovenia. Alpine karst locations are 1, 2, 3, 4, 5, 16, 25; Isolated karst locations are 6, 21, 26; Dinaric karst locations are 7, 8, 9, 10, 11, 12, 13, 14, 15, 17, 18, 19, 20, 22, 23, 24.

Legend: 1 Mežakla, 2 Pokljuka, 3 Jelovica, 4 Menina, 5 Dobrave, 6 Hrastovec, 7 Kočevsko Ribniško polje, 8 Bela krajina, 9 Logaški ravnik, 10 Hrušica, 11 Trnovski gozd, 12 Podgrajsko podolje, 13 Kras, 14 Podgorski kras are examined and presented in the text and on the maps. Other areas: 15 Banjšice, 16 Dobrovlje, 17 Hotenjski ravnik, 18 Javorniki, 19 Nanos, 20 Postojnski kras, 21 Šentviška planota, 22 Snežnik, 23 Trnovski gozd SZ, 24 Trnovski gozd JV, 25 Velika planina, 26 Zasavje are examined only in Tab. 2. 


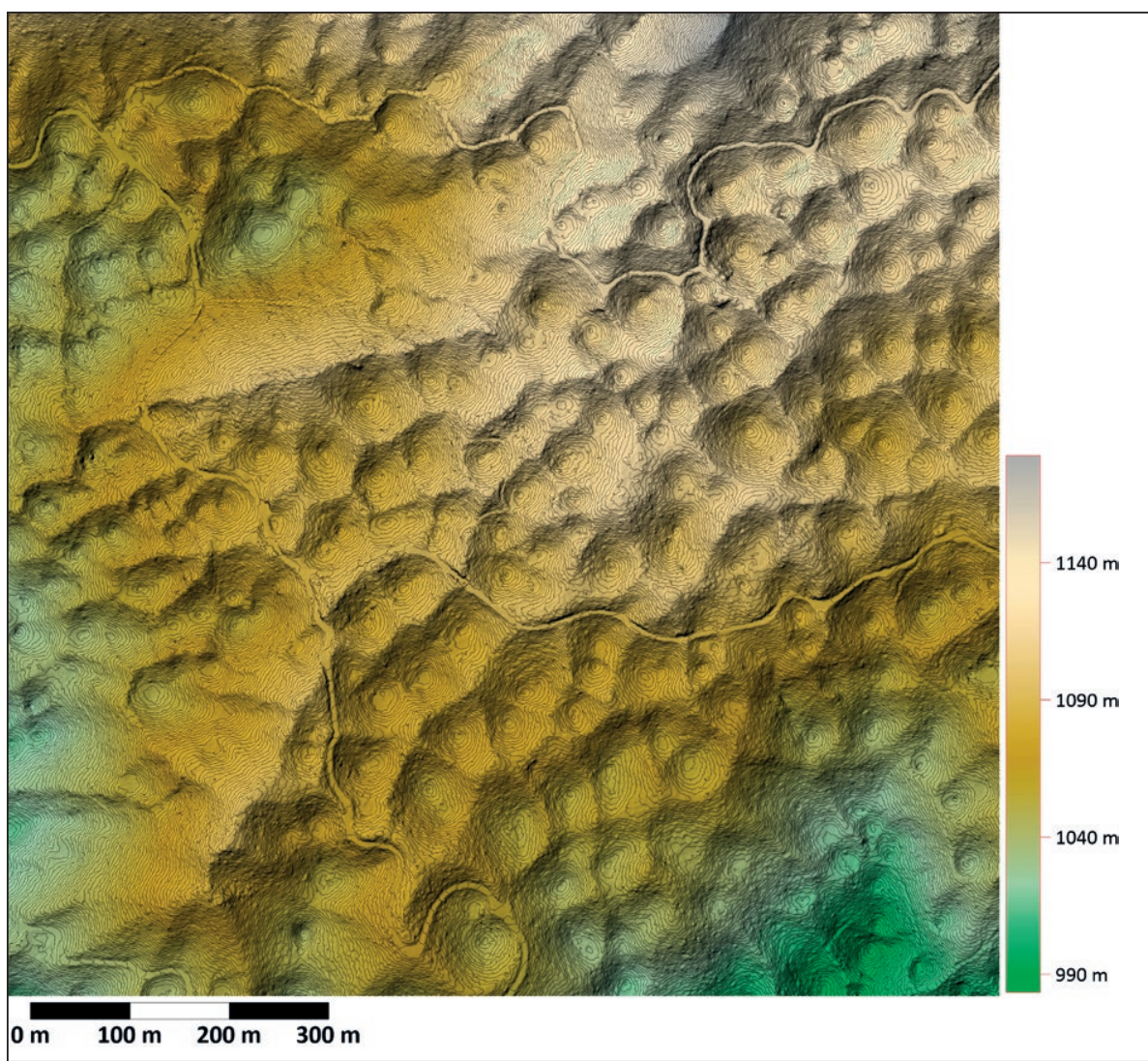

Fig. 7: Characteristic part of the surface of Mežakla with dolines. There are 222 dolines on the selected square kilometre of the territory. Their size varies from the smallest with a diameter of about $20 \mathrm{~m}$, to about $80 \mathrm{~m}$. The contour interval is $2 \mathrm{~m}$.

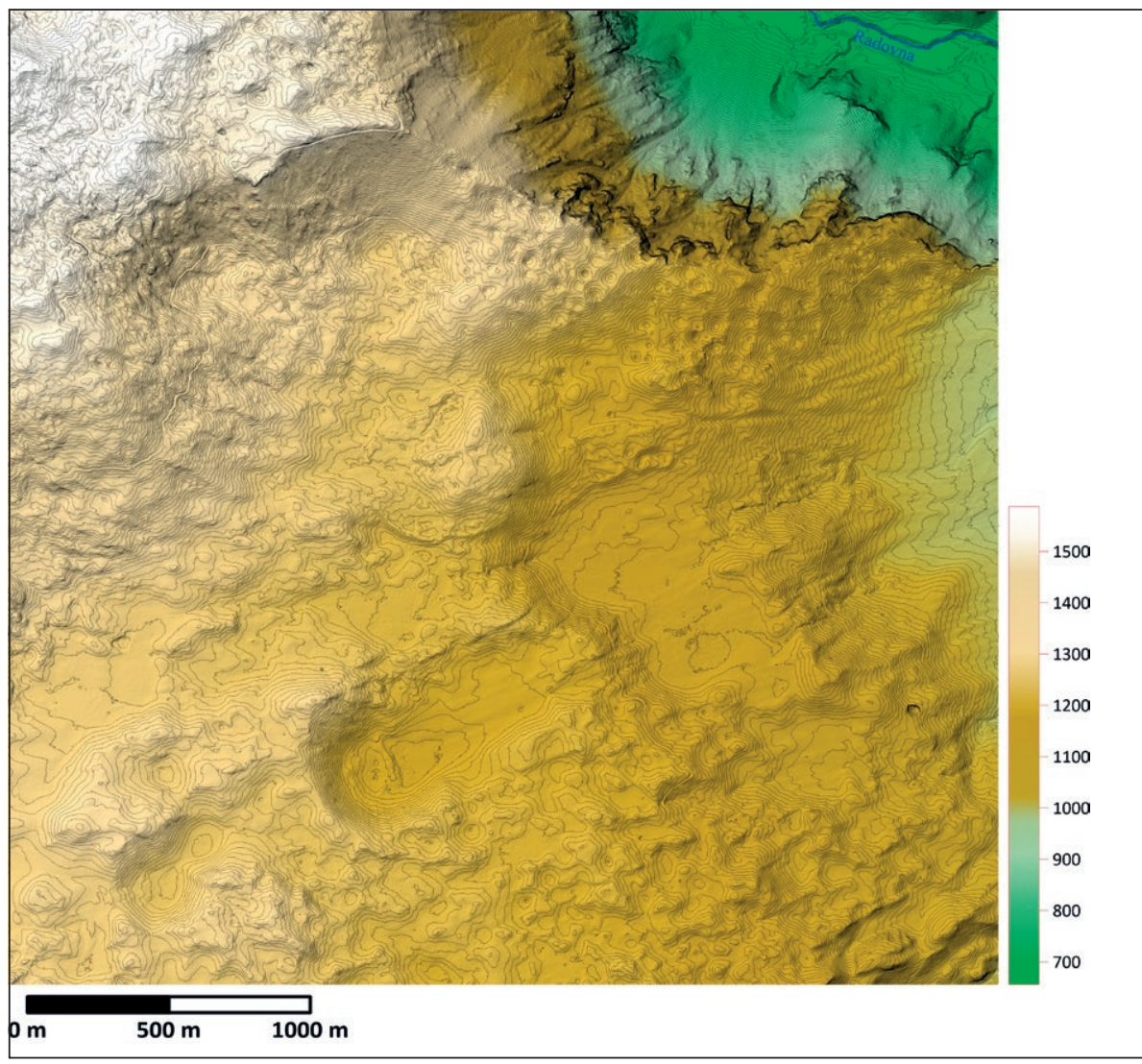

Fig. 8: Surface of Pokljuka with dolines and traces of glaciation. The glacier ran from southwest to northeast. North of the glacier, dolines have been preserved on the edge of the plateau that was not covered by the glacier. In the central part, the glacier covered the dolines with moraine material. The contour interval is $4 \mathrm{~m}$. 
dolines are formed in glacial deposits covering the floors of various depressions. Here we present the characteristics of dolines within specific karst areas (1-5 in Fig. 6).

Mežakla (No. 1 in Fig. 6) is a $10 \mathrm{~km}$ long and up to $2 \mathrm{~km}$ wide plateau. It is built of Triassic limestones and dolomites. It is surrounded by deep river valleys so the vadose zone in the plateau is up to several hundred metres deep. The undulating plateau rises from an altitude of about $900 \mathrm{~m}$ to an altitude of $1450 \mathrm{~m}$. At the highest part, it is only about $400 \mathrm{~m}$ wide. Despite the high altitude, there are no traces of glaciation on the surface of the plateau. The slopes of the dolines are rocky and thicker soil at the bottom covers the floors.

The entire plateau is covered by a dense network of solution dolines reaching a density of up to 138 per $\mathrm{km}^{2}$. A typical part of the plateau surface is presented in Fig. 7. The average diameter of these dolines is $46.8 \mathrm{~m}$ and the average depth is $12 \mathrm{~m}$. They are arranged so that they grow into each other and form a polygonal grid without an intermediate flat surface.

There are no dolines with clear signs of collapse morphogenesis on the surface of the plateau. There are also no suffosion dolines.

Pokljuka (No. 2 in Fig. 6) is a plateau of about 60 $\mathrm{km}^{2}$ at altitudes between 1100 and $1400 \mathrm{~m}$. It is separated from Mežakla only by the deeply incised valley of Radovna. Initially Pokljuka was dissected entirely by solution dolines in the same way as Mežakla. In the last glaciation, it was covered by a plateau glacier that had originated on the higher part of the plateau (Bavec \& Verbič 2004). It eroded most of the dolines or covered them by glacial deposits, which is visible from the lidar-derived DEM. Ground and lateral moraines are also well expressed on the DEM. Dolines covered by the glacier were somewhat blurred and dolines not reached by the glacier are clearly visible and are similar to dolines from Mežakla plateau.

After the last glaciation, many smaller suffosion dolines formed where glacial sediments cover the underlying karst. Pokljuka is dominated by funnel-shaped suffosion dolines that are a few metres deep and wide. There are no dolines with clear signs of collapse genesis on the surface of Pokljuka. The glaciated karst plateau surface with dolines is presented in Fig. 8.

Jelovica (No. 3 in Fig. 6) is a plateau of about 50 $\mathrm{km}^{2}$ with most of the surface between 1100 and $1200 \mathrm{~m}$ above sea level and individual peaks up to $1400 \mathrm{~m}$ above sea level. It is built of Triassic dolomites and limestones which are deformed by tectonics. Among them, there are

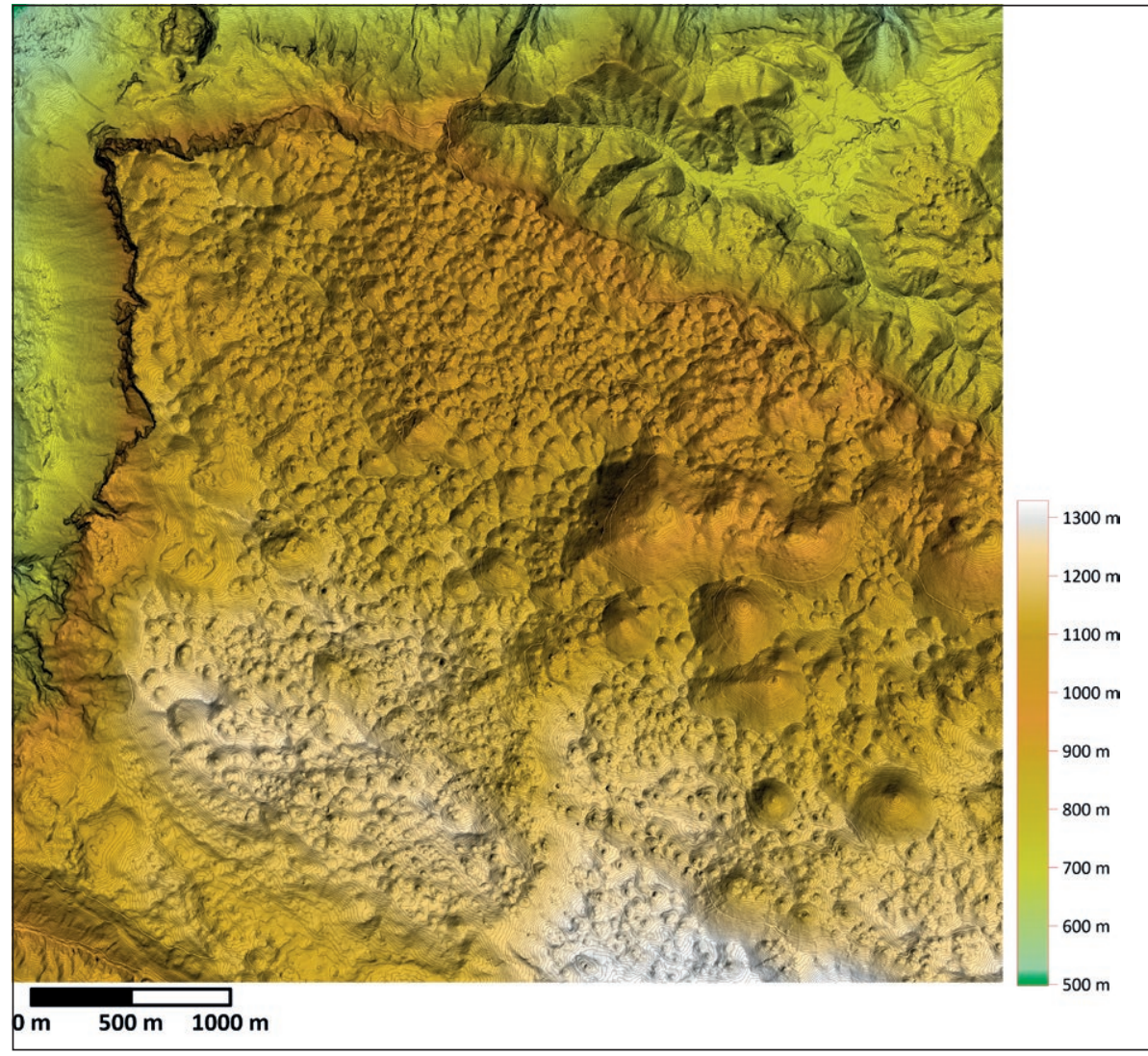

Fig. 9: Central part of the Jelovica plateau. Small dolines prevail and, only in the southeastern part, there is a group of large dolines called kontas. Their origin is not clear. They may belong to an older generation of dolines. The contour interval is $4 \mathrm{~m}$. 

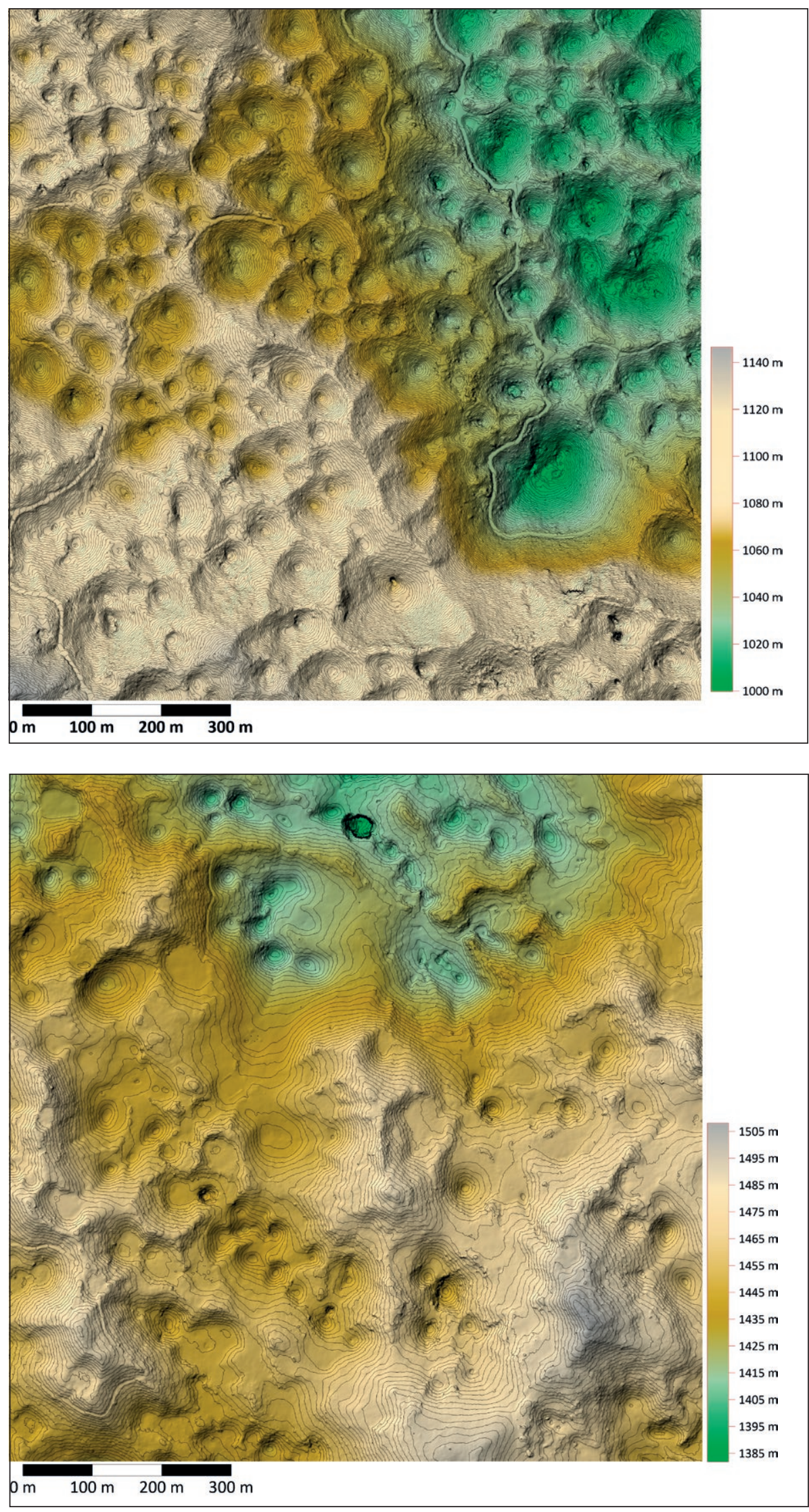

Fig. 10: Typical surface with dolines on Jelovica. There are 211 dolines per square kilometer. Dolines connect and create a polygonal network without a flat surface in between. The entire surface shown in the figure belongs to the slopes of the dolines. Doline size varies from the smallest with a diameter of about $40 \mathrm{~m}$ to the large kontas with diameters up to $300 \mathrm{~m}$. Open or collapsed entrances to the shafts are also visible in some dolines. The contour interval is $4 \mathrm{~m}$.
Fig. 11: Surface with dolines on Menina planina. It was formed on dolomitized limestones and dolomite. It is covered by dolines of different sizes possibly belonging to different generations. Among them are also dolines with steep edges indicating a possible collapse genesis over larger cavities. At the bottom of the dolines, there are some larger flat surfaces formed of periglacial gravel. The contour interval is $4 \mathrm{~m}$. 
also some smaller patches of non-carbonate lithology on which a network of surface streams has developed, which provide small scale allogenic recharge to adjacent karst areas. Jelovica is separated from Pokljuka by the Sava river canyon. Other edges of the plateau are determined by tectonic fault lines along which steep slopes of the plateau were formed. The depth of the vadose zone is over $500 \mathrm{~m}$, as evidenced by the deep caves. The surface of the plateau was not glaciated. The slopes of the dolines are rocky and the soil is deeper at the floors of the dolines. Most of the plateau is covered by a dense network of solution dolines. The dolines merge with each other to form a polygonal karst grid with no flat surfaces in between. Dolines are scarce on the slopes of the hills that rise above the levelled part of the plateau and are completely absent on the slopes bounding the plateau. The central part of the plateau surface is presented in Fig. 9., and its typical doline karst in Fig. 10.

Most dolines are between 19 and $90 \mathrm{~m}$ in diameter, are on average $12 \mathrm{~m}$ deep, and do not have flat floors. In the network of these dolines, there are also some much larger dolines. The diameters of these dolines reach from a few $100 \mathrm{~m}$ up to $1000 \mathrm{~m}$ and they can be over $100 \mathrm{~m}$ deep. The exact genesis of this larger doline type, known locally as konta, is not clear. At the bottom of the larger dolines, smaller suffosion dolines formed on thicker sediments. There are no collapse dolines on the plateau.

On other Alpine plateaus such as Velika planina, Menina planina (No. 4 in Fig. 6) and Dobrovlje, the spatial distribution and morphology of the dolines are different. This is a result of their different geological settings, and especially due to the presence of thin-layered limestones and limestones with impurities and layers of non-carbonate rocks. Solution dolines are most common, while suffosion dolines are few and are confined to sites with Pleistocene deposits. Part of the Menina planina karst surface with dolines is presented in Fig. 11.

Dolines on conglomerate terraces at the southern foot of the Alps were formed on carbonate conglomerates in the Ljubljana Basin. The tectonic basin is filled by conglomerates that are organised in a series of terraces that are a result of sedimentation and erosion phases during Pleistocene climate oscillations. This created a series of older conglomerate terraces and younger terraces of non-consolidated deposits (Šifrer 1969). The oldest conglomerate terrace is dated to $1.8 \mathrm{Ma}$ while the youngest conglomerate terraces were formed in the Late Pleistocene (Mihevc et al. 2015).

The surface of the terraces, especially the older ones, is flat and covered by solution dolines. On the younger terraces, the dolines are smaller and shallower. They are

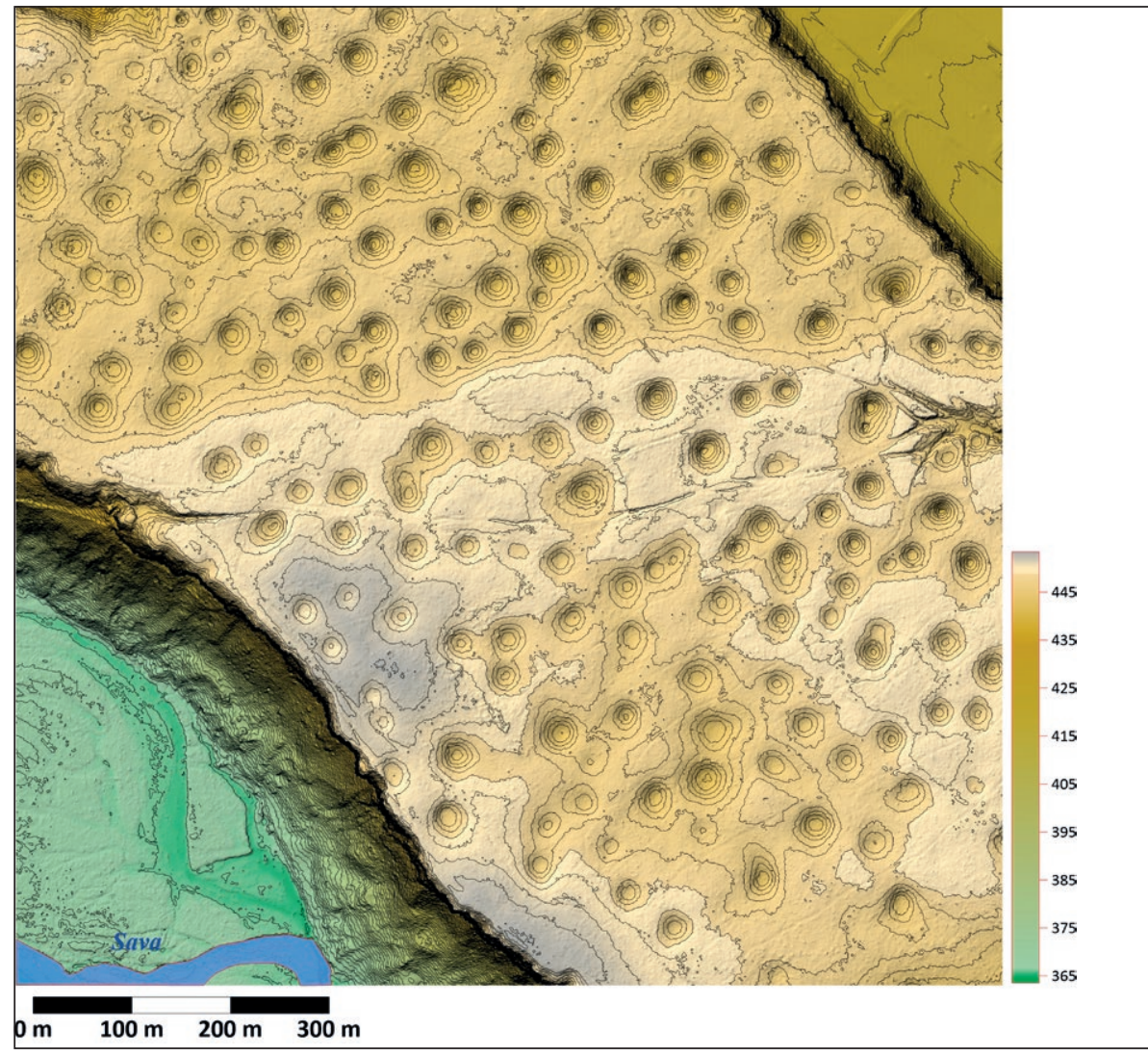

Fig. 12: Dolines cover the Pleistocene terrace on Dobrave, which lies $80 \mathrm{~m}$ above the current riverbed of the Sava river. The terrace is dated to the Middle Pleistocene according to the sequence in a series of Sava terraces, which is the only method available for dating the terrace. It is composed of conglomerates in which carbonate pebbles are most common; also, the cement is of carbonate composition. A thick soil has already formed on the terrace. The contour interval is $1 \mathrm{~m}$. 
completely absent on the Holocene terrace. The number of dolines on conglomerate terraces is 3417 and their density is 75 per $\mathrm{km}^{2}$. A lot of flat surfaces are preserved between the dolines so the dolines do not merge. The share of dolines is $7.6 \%$ of the surface. The typical doline karst of Dobrave (No. 5 in Fig. 6) is presented in Fig. 12.

\section{DOLINES OF THE ISOLATED KARST}

Isolated karst formed on smaller patches of limestones and dolomites surrounded by non-carbonate rocks. Each such patch has its own genesis and age. Isolated karst has developed in the area between the Alps and Dinaric Mountains at altitudes typically between 150 and $800 \mathrm{~m}$. Doline morphology and evolution are generally defined by the local setting of each karst area. Submerging rivers and underground streams that cross them are common. Isolated karst areas are small. The largest is only several tens of $\mathrm{km}^{2}$ large.

As the isolated karst has no common characteristics, its dolines are also very different in number and shape. The dolines are most numerous on levelled surface areas. The isolated karst often has thicker soils formed on the surface and in the dolines that were formed by mechanical weathering of allogenic alluvial sediments. Therefore, smaller suffosion dolines are more common in this karst. Here we present dolines of karst area No. 6 in Fig. 6.
The isolated karst of Slovenske gorice lies on the western outskirts at altitudes between 200 and $400 \mathrm{~m}$. Precipitation there is low due to the continental climate and low altitude, only amounting to $1000 \mathrm{~mm}$ yearly. It is built of Neogene limestones with many impurities. Therefore, a relief that developed on them formed into ridges and valleys with rare karst features. The isolated karst of Slovenske gorice is also the easternmost region in Slovenia where dolines can still be found. The most common are solution dolines and suffosion dolines. The dolines formed on smaller levelled surfaces and where the surface is less inclined. The typical dolines of this area are found between Maribor and Hrastovec (No. 5 in Fig. 6) and are presented in Fig. 13. The dolines are between 18 to $68 \mathrm{~m}$ in diameter. Their share on the surface is small. Due to the impure limestones, the surface is covered with a continuous soil layer so the surface is not covered by grikes; and, there is more soil in the dolines. Funnel-shaped suffosion sinks up to a few metres deep formed in them.

\section{DOLINES OF THE DINARIC KARST}

Dinaric karst is the major karst area of Slovenia and is also the main type of relief of the Dinaric Mountains. It has formed on Paleozoic, Mesozoic and Cenozoic limestones and dolomites in the area of the Dinaric Carbonate Platform (Placer 1981, 1998).

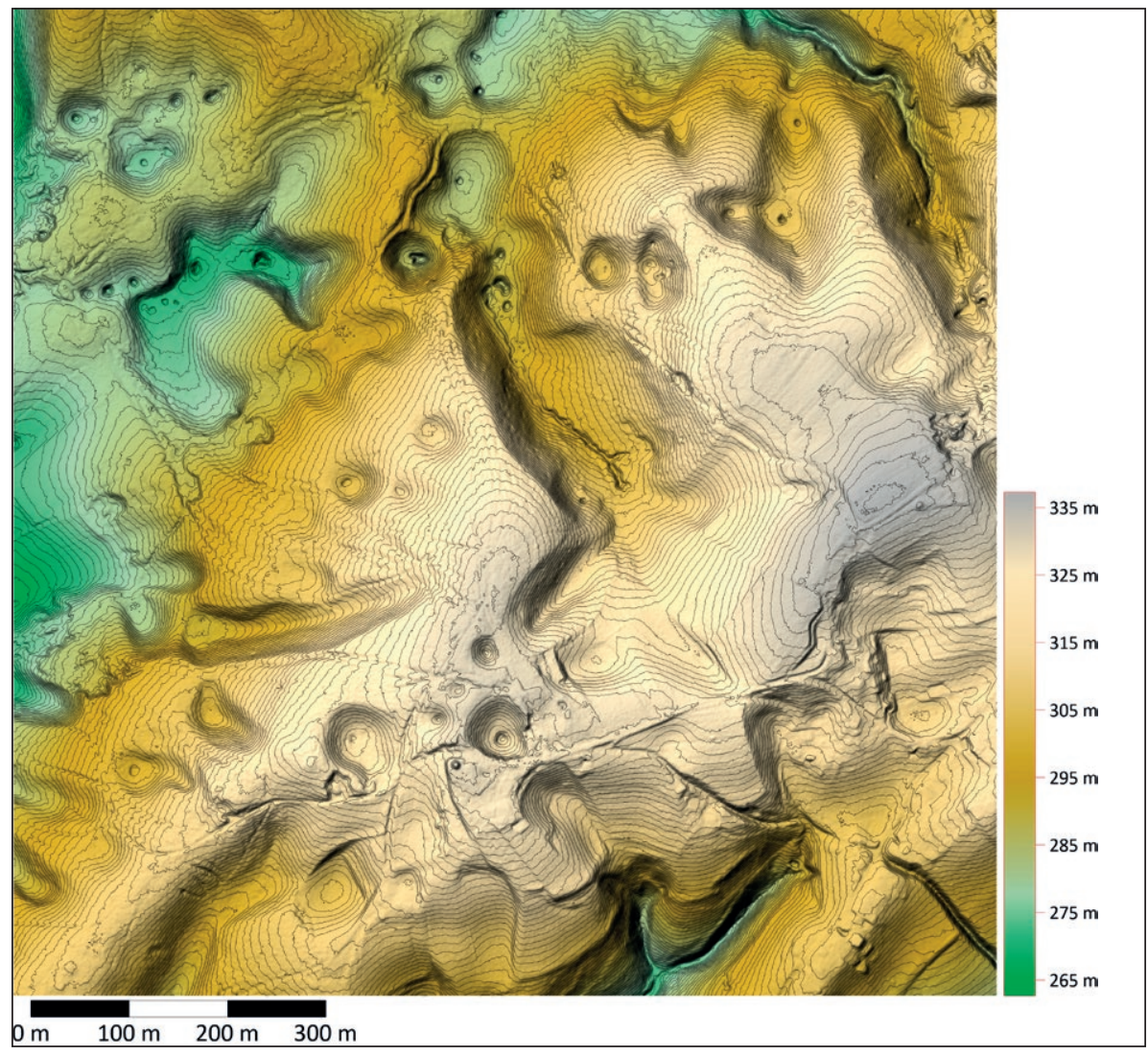

Fig. 13: Isolated karst between Maribor and Hrastovec, formed on Miocene limestones. Limestones contain a lot of impurities so in some places the surface runoff has been preserved and smaller fluvial valleys have formed ending in blind valleys. There is a layer of regolith up to half a metre thick on the surface. Rare dolines have formed on the flatter surface. Special features are the many small suffosion sinks that formed either on the surface in thick soil or mostly in the bottom of the dolines. Dolines are up to $5 \mathrm{me}$ tres deep and just as wide in diameter. They are formed by suffosion sinks that in some places reach the bedrock and continue into impassable caves. The figure shows $1 \mathrm{~km}^{2}$ of surface area, the contour interval is $1 \mathrm{~m}$. 
Current major relief units are connected with late Tertiary tectonic evolution that gradually separated the older levelled surface into individual units. These units were formed in different conditions, so each of them has its shape, size and distribution of dolines. Denudation removed the upper part of the karst exposing old caves which merged into the recent surface densely populated with solution dolines. We present dolines from some of these units, karst area numbers 7-25 from Fig. 6.

The central part of the Dinaric Mountains of Slovenia consists of a series of 1000-1700 m high karst plateaus. From them, lower karst plateaus and planation surfaces gradually descend on both sides. The lowest plateau on the littoral side is Kras (No. 13 in Fig. 6). The lowest inland levelled surface is Bela Krajina (No. 8 in Fig. 6) at below $200 \mathrm{~m}$ above sea level. Surface rivers appear only where the water table level within the karst aquifer is close to the surface. Allogenic rivers flowing from non-carbonate rocks either sink at the karst boundary forming blind valleys and ponor steepheads or they flow across the karst in canyons. The lowest littoral karst receives around 1400 $\mathrm{mm}$ of precipitation, the crest of the Dinaric Mountains receives $2000-3000 \mathrm{~mm}$, and the inland about $1500 \mathrm{~mm}$. The karst water table is generally several hundred metres below the surface. During Pleistocene glaciations, the glacial equilibrium line altitude was about $1200 \mathrm{~m}$ above sea level, so some of the plateaus were glaciated, but glaciers only slightly modified the karst topography.

Dolines are the most common form and are present on all types of relief of the Dinaric karst. At the same time, all genetic types of dolines are present here. The main factor determining the density of dolines is the slope of the surface on which they form. The secondary factor is the type of carbonate rock. The density of dolines is generally lower on dolomites. It is highest on limestones and on levelled surfaces along the edges of karst poljes where the number of dolines reaches up to 500 per $\mathrm{km}^{2}$ and cover up to $60 \%$ of the surface. Small dolines with a diameter of 14 to $79 \mathrm{~m}$ are the most common (see Tab. 2). On older levelled surfaces, where the water level of the karst water is already deep below the surface, dolines tend to be larger.

Dolines are bigger on the older karst plateaus but less numerous (100-200 per $\left.\mathrm{km}^{2}\right)$ and cover a smaller share of the surface. The distribution of dolines in some places reflects a strong correlation to geological structures, to stratification and faults. In the absence of strong geological features, the distribution is random, linked to the general permeability of the karst. In most cases, there is a lot of flat surface between dolines that is not part of them (see Fig. 24). Rarely, especially on high plateaus, dolines form polygonal networks and are completely adjacent to one another (see Fig. 21).

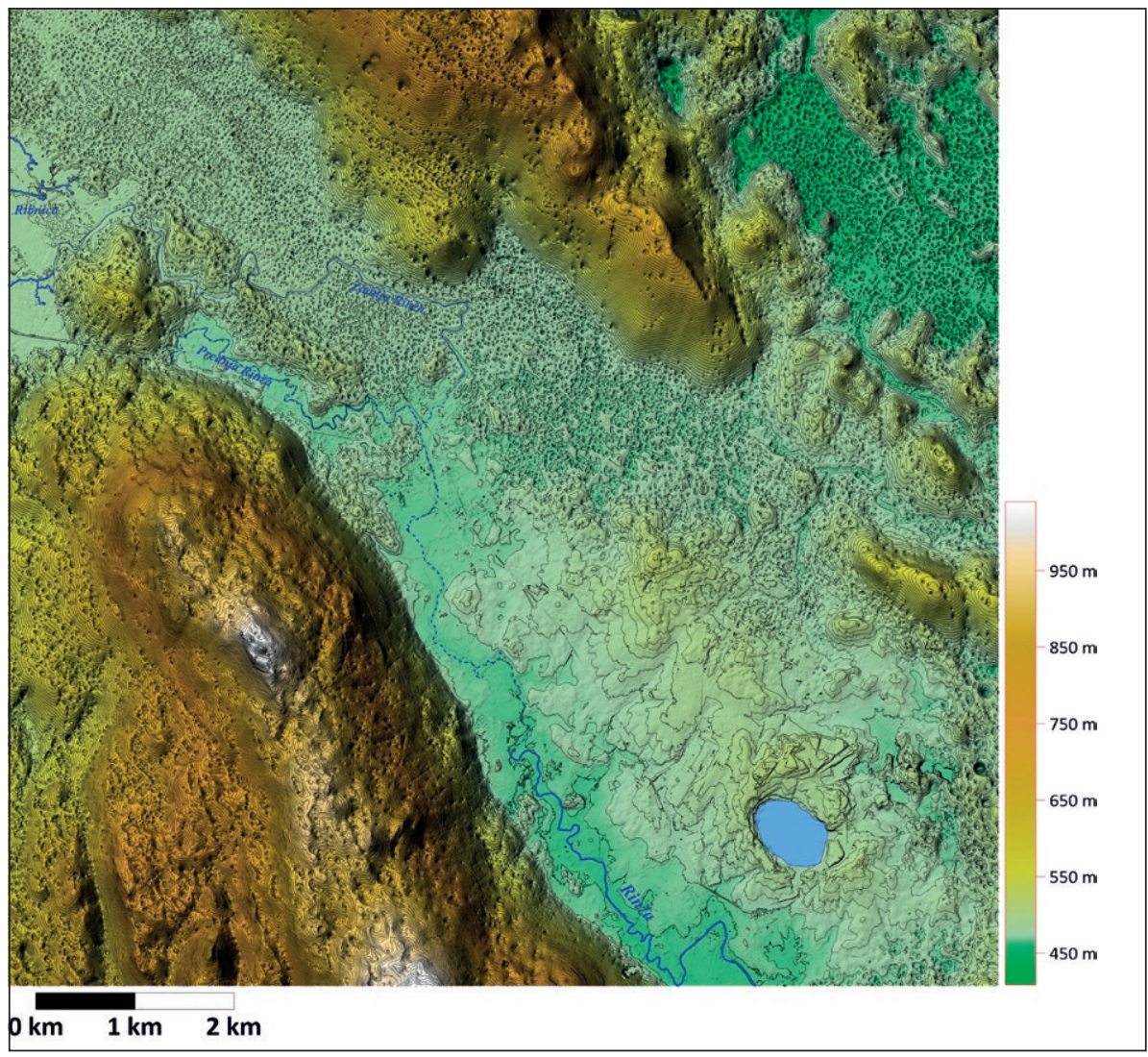

Fig. 14: The central part of the Kočevsko Ribniško polje between Velika gora in the northeast and Stojna in the southwest. The water of the Ribnica river sinks and flows to Krka and Rinža. There arefloods only in the southwestern part of the polje. There is a higher terrace with dolines on the northeastern edge of the polje. There are notable differences between the density and size of the dolines on the polje and on the hilly sloping relief. The contour interval is $5 \mathrm{~m}$. 

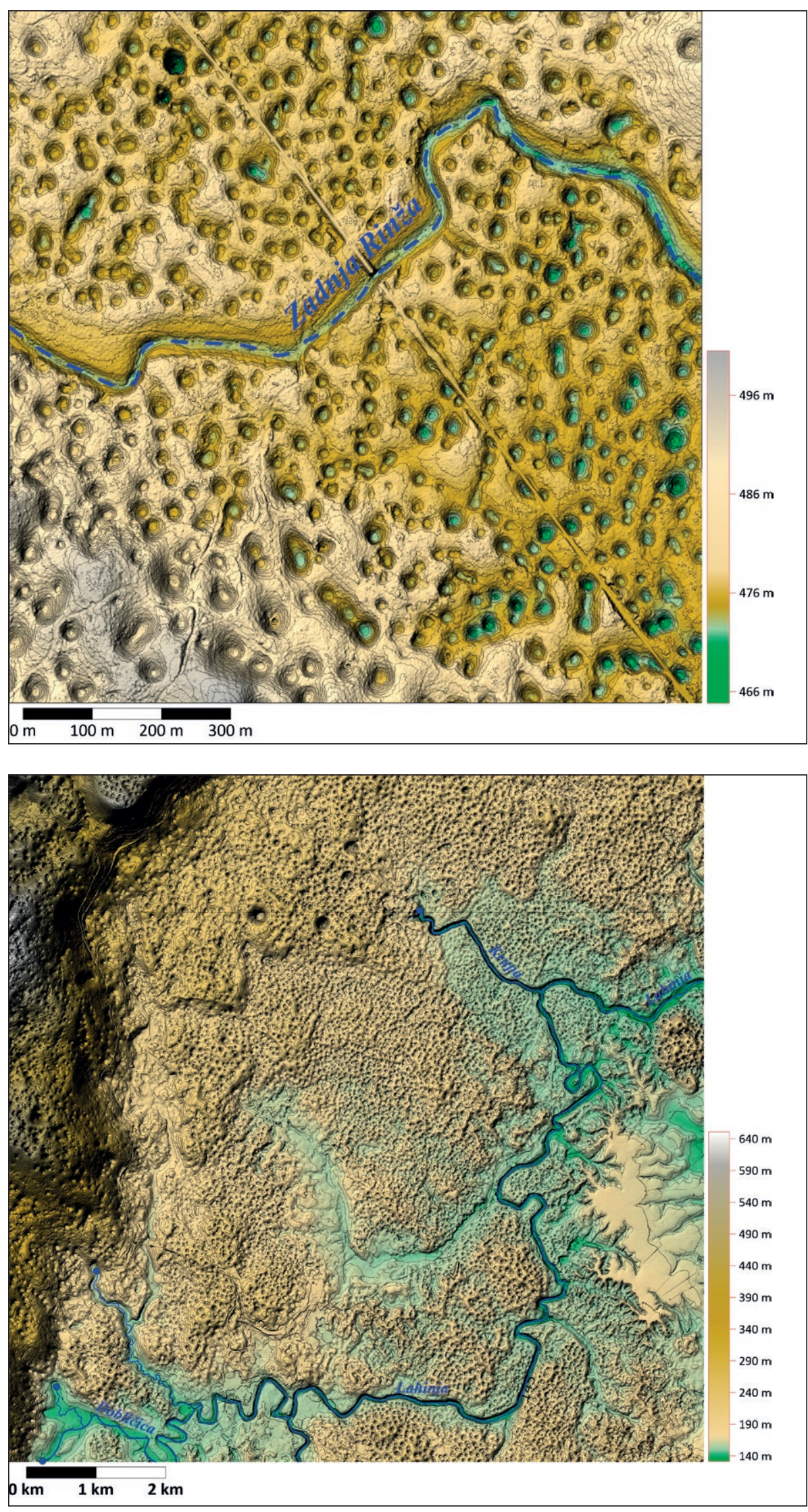

Fig. 15: ̌̌ahen - part of Kočevsko Ribniško polje. At the edge of Kočevsko Ribniško polje lies an extensive rocky terrace called Šahen. It formed on the level of the floor of the polje. Today it is mostly raised about $10 \mathrm{~m}$ above the height of the flood plain of both poljes. During floods in the Ribniško polje, water occasionally still flows through a shallow, about $5 \mathrm{~m}$ deep, canyon in Šahen to the Kočevsko polje. There are floods every few years and groundwater floods the nearby dolines too. The figure shows $1 \mathrm{~km}^{2}$ of surface area, the contour interval is $1 \mathrm{~m}$.
Fig. 16: Bela krajina lies at the foot of the high karst. It is part of a former large levelled surface that has disintegrated into smaller units. As it rose, rivers emanating from the springs located below the high karst began to carve into it. At the same time, dolines started to develop. The contour interval is $5 \mathrm{~m}$. 
On inclined surfaces, dolines are generally sparser but often slightly larger and stretched upwards along the slope. However, they are completely absent on steeper slopes with an inclination above $20^{\circ}$. Dolines are also absent from the floor of poljes where there are floods or the level of karst water is just below the surface. Dolines on poljes may also be covered with Pleistocene sediments and therefore not visible.

Kočevsko Ribniško polje (No. 7 in Fig. 6) is the largest polje on the Dinaric karst in Slovenia. The lowest parts of the polje are flat and have regular floods. Most of the polje is covered by alluvium, which was deposited either by streams flowing into the polje or during floods. In the lowest part of the polje, suffosion dolines occur as a result of fluctuations of the water table level that can be observed $20 \mathrm{~m}$ below the surface in water shafts at low water levels.

At the edge of the floodplain, there is a surface about $10 \mathrm{~m}$ higher that floods no longer reach. The dolines of Kočevsko Ribniško polje (No. 5 in Fig. 6) are presented in Fig. 14, and a selected part of it (the Šahen area) in larger scale in Fig. 15. The polje's surface is dissected by solution dolines, which reach up to 500 dolines $/ \mathrm{km}^{2}$. These dolines are small, up to $40 \mathrm{~m}$ in diameter. They cover about $60 \%$ of the surface.

Bela krajina (No. 8 in Fig. 6) is a large levelled sur- face at an altitude of between 150 and $300 \mathrm{~m}$. Towards the east, the levelled surface continues at the same altitude. Most of Bela krajina is built of Mesozoic limestone and only a small part is covered by Neogene non-carbonate sediments. It is surrounded from the north and west by higher karst plateaus, which reach up to $1000 \mathrm{~m}$ above sea level. At the foot of these karst plateaus and on the levelled surface, there are large karst springs of rivers that cross the surface in shallow, up to $20 \mathrm{~m}$ deep, canyons.

The levelled area is covered by a dense network of solution dolines between $21 \mathrm{~m}$ and $62 \mathrm{~m}$ in diameter that occupy about $21 \%$ of the surface. The surface is covered with continuous layers of soil, so it is not rocky and between the dolines there is a lot of flat surface.

Four shallow collapse dolines that are on average 6.7 $\mathrm{m}$ deep and up to $300 \mathrm{~m}$ in diameter formed in the northern part of Bela krajina above the source of the Krupa river (Fig. 16). The typical dolines along Krupa canyon are presented in Fig. 17.

Logaški ravnik (No. 9 in Fig. 6) is a levelled surface approximately $15 \mathrm{~km}$ long and up to $3 \mathrm{~km}$ wide. It was formed as a part of a former large karst polje (Gams 1974), which due to tectonic displacements in the Idrija fault zone, disintegrated into smaller parts. Logaški ravnik was uplifted and today lies about $100 \mathrm{~m}$ above the nearby active Planinsko polje, which lies at an alti-

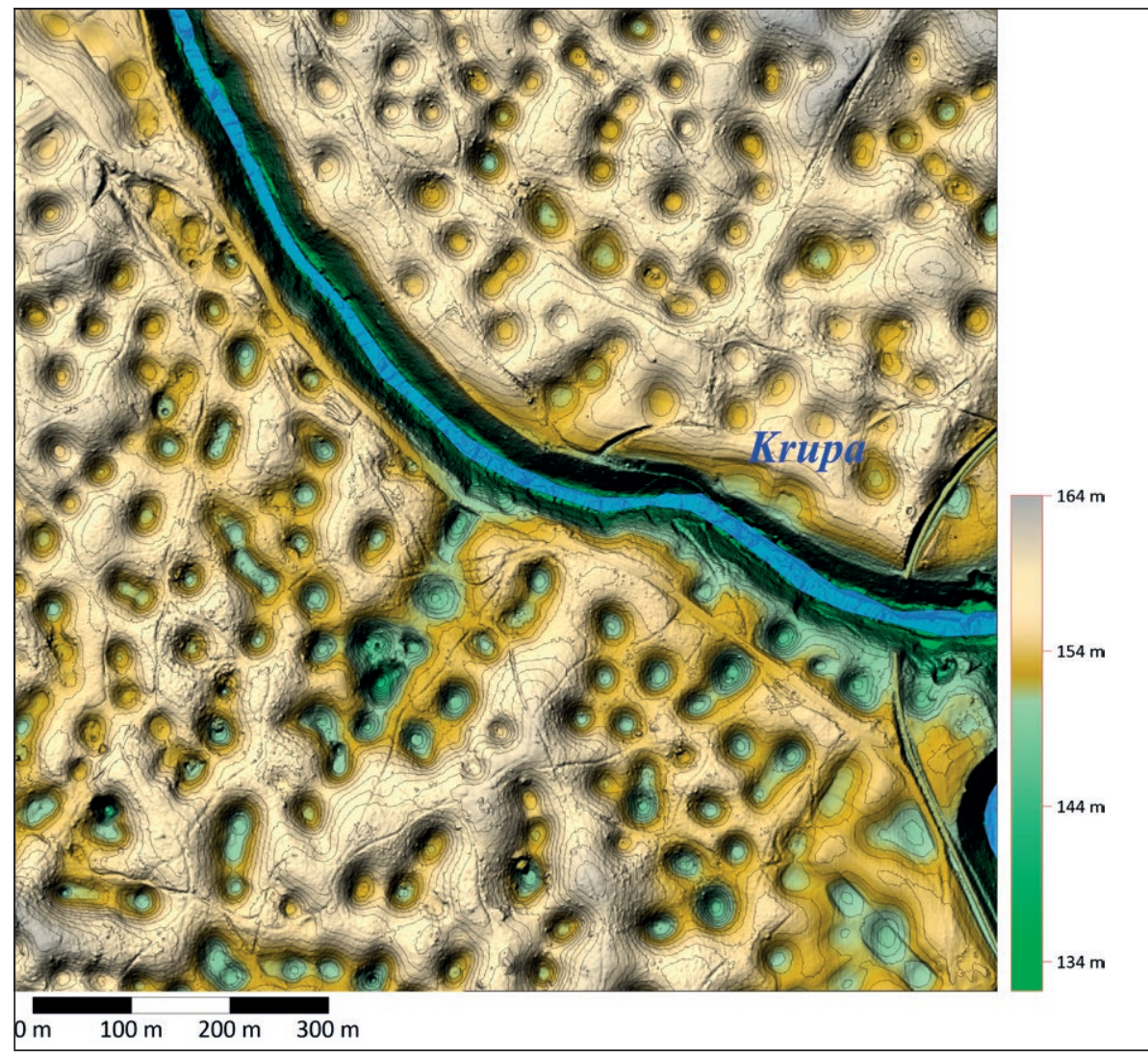

Fig. 17: Dolines in Bela krajina along the canyon of the Krupa river. The surface is covered by a continuous and up to $2 \mathrm{~m}$ thick layer of soil. Some more soil is at the bottom of the dolines. In some places, shallow suffosion dolines appear in them. The contour interval is $1 \mathrm{~m}$. 

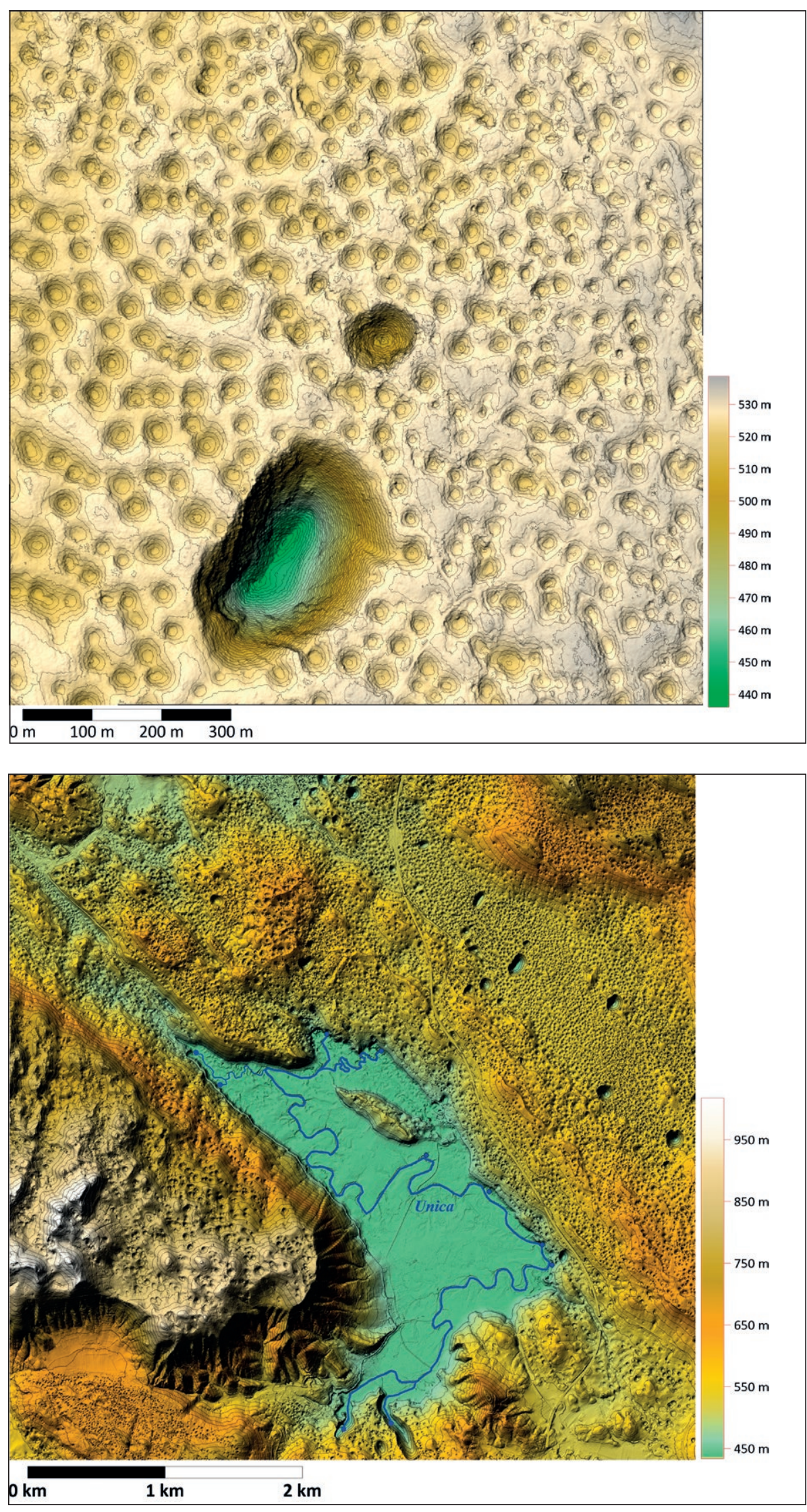

Fig. 18: Dolines on the surface of Logaški ravnik with two collapse dolines - larger Laška kukava and smaller Kukavica. Solution dolines are shallow and up to $50 \mathrm{~m}$ wide and are different from the collapse dolines that formed above the caves and underground streams of the Ljubljanica river. The contour interval is $1 \mathrm{~m}$.
Fig. 19: Diversity of dolines on three relief units. Planinsko polje is in the middle. It is crossed by the Unica river, which originates from the caves in the south of the polje, crosses it and sinks at its northern edge. West of the polje is the high plateau Hrušica. Northeast of the polje lies Logaški ravnik, which is a surface stretching in the northwest to southeast direction. Numerous dolines are carved into the flat surface of Logaški ravnik. Large collapse dolines formed above the underground caves through which the Unica flows to the north. The contour interval is $20 \mathrm{~m}$. 
tude of about $450 \mathrm{~m}$. Logaški ravnik is built of Mesozoic limestones and dolomites. Cretaceous limestones dip at an angle of $20^{\circ}$ to the west. The levelled surface, which was formed as part of the karst polje and was originally in an approximately horizontal position, is today tilted to the northeast and lies between altitudes of 480 and $610 \mathrm{~m}$. There are several caves in the area in which we can reach the underground flow of the river Ljubljanica, which flows about 100 to $150 \mathrm{~m}$ below the surface. In one of the caves in the area, the underground flow of the river can be reached about $100 \mathrm{~m}$ below the current surface around Laška kukava. Groundwater fluctuations of about $50 \mathrm{~m}$ can be observed in the caves (Turk et al. 2010).

The surface is covered by a dense network of solution dolines, which are rarer or absent only on dolomite. The maximum density of dolines is around 400 per $\mathrm{km}^{2}$. They occupy about $35 \%$ of the total surface of Logaški ravnik. These dolines do not show a pronounced correlation to tectonic lines. Part of the doline karst from Logaški ravnik is presented in Fig. 18.

There are 26 large collapse dolines on Logaški ravnik, which are up to $100 \mathrm{~m}$ deep and up to $370 \mathrm{~m}$ in diameter. They either follow the underground flow of the Ljubljanica or they are in the hinterland of the Planinsko polje ponors.

The diversity of dolines on three relief units -
Logaški ravnik, Planinsko polje, and Hrušica high karst plateau - is presented in Fig. 19.

Hrušica (No. 10 in Fig. 6) is a karst plateau about 20 $\mathrm{km}$ long and up to $10 \mathrm{~km}$ wide with a surface at altitudes between 800 and $1200 \mathrm{~m}$. It is built of limestone which belongs to two thrust units (Placer 1981). The thin soil cover is not continuous, so the surface is rocky. The originally more levelled surface is divided into smaller relief units - up to one-kilometre wide uvalas, smaller levelled areas with numerous dolines, intermediate steep bends and conical hills.

Hrušica lies in the central part of the Dinaric Mountain range and has from 1600 to $2500 \mathrm{~mm}$ of precipitation. The water drains underground to springs in the surroundings below the edge of the plateau. According to the depth of the shafts, the depth of the vadose zone is more than $250 \mathrm{~m}$ everywhere.

Hrušica differs from neighbouring plateaus by having a large number and density of solution dolines. Most dolines have a diameter of 17 to $67 \mathrm{~m}$. However, much larger dolines with a diameter of up to half a kilometre are also common. The dolines are deep and have steep slopes. On average, there are 139 dolines per $\mathrm{km}^{2}$ on the plateau and their share of the surface is around $20 \%$. There are no suffosion or collapse dolines on Hrušica. A typical part of the doline karst from Hrušica is presented in Fig. 20.

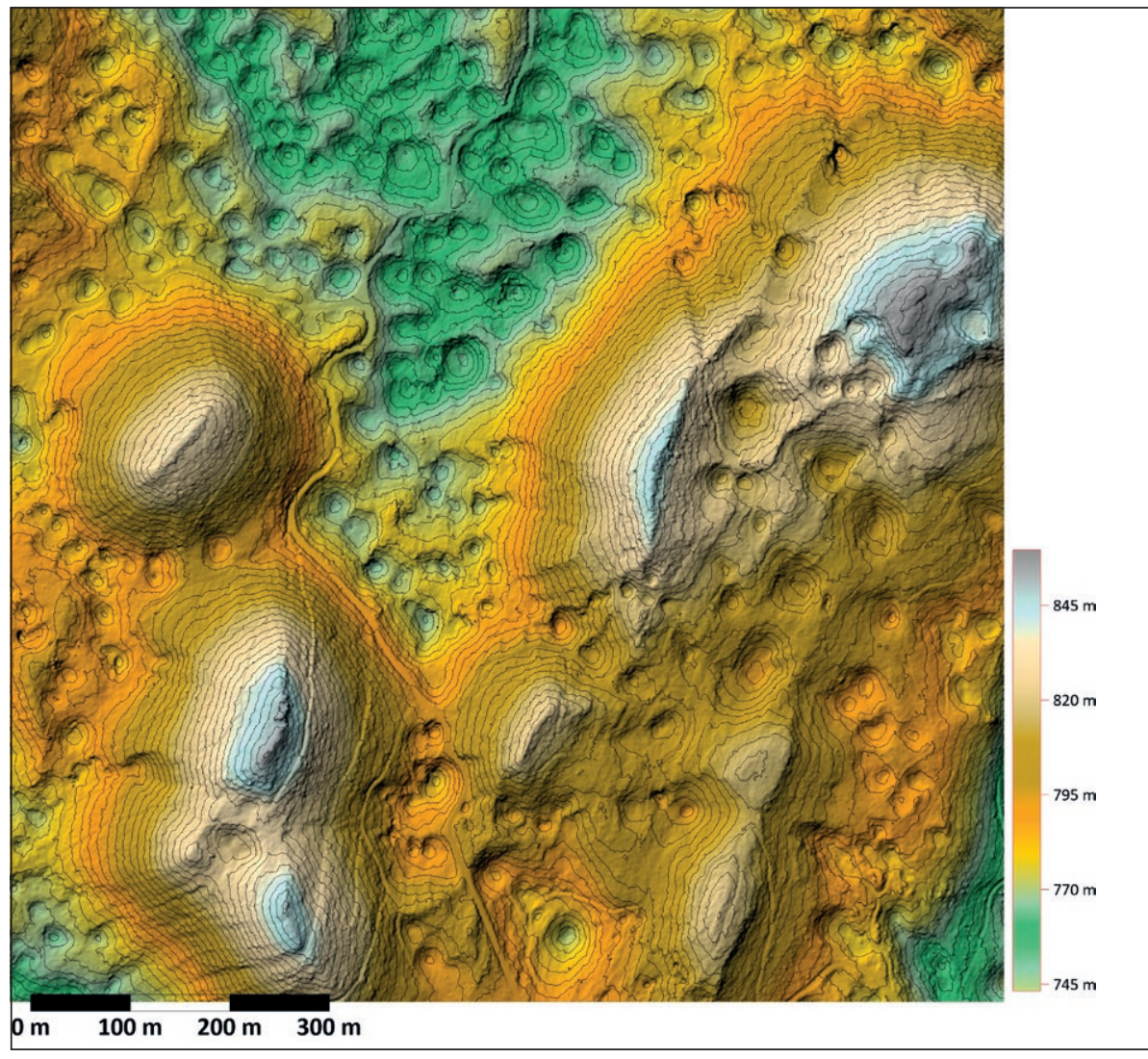

Fig. 20: Dolines and conical hills of Hrušica. The uneven surface of the plateau is divided by conical hills and intermediate uvalas as well as smaller levelled surfaces. Dolines have formed only on surfaces with a smaller slope. Their network is very uneven. In some places, dolines continue into one another while in other places they are arranged in rows between conical peaks that stand out with long smooth slopes. The contour interval is $3 \mathrm{~m}$. 

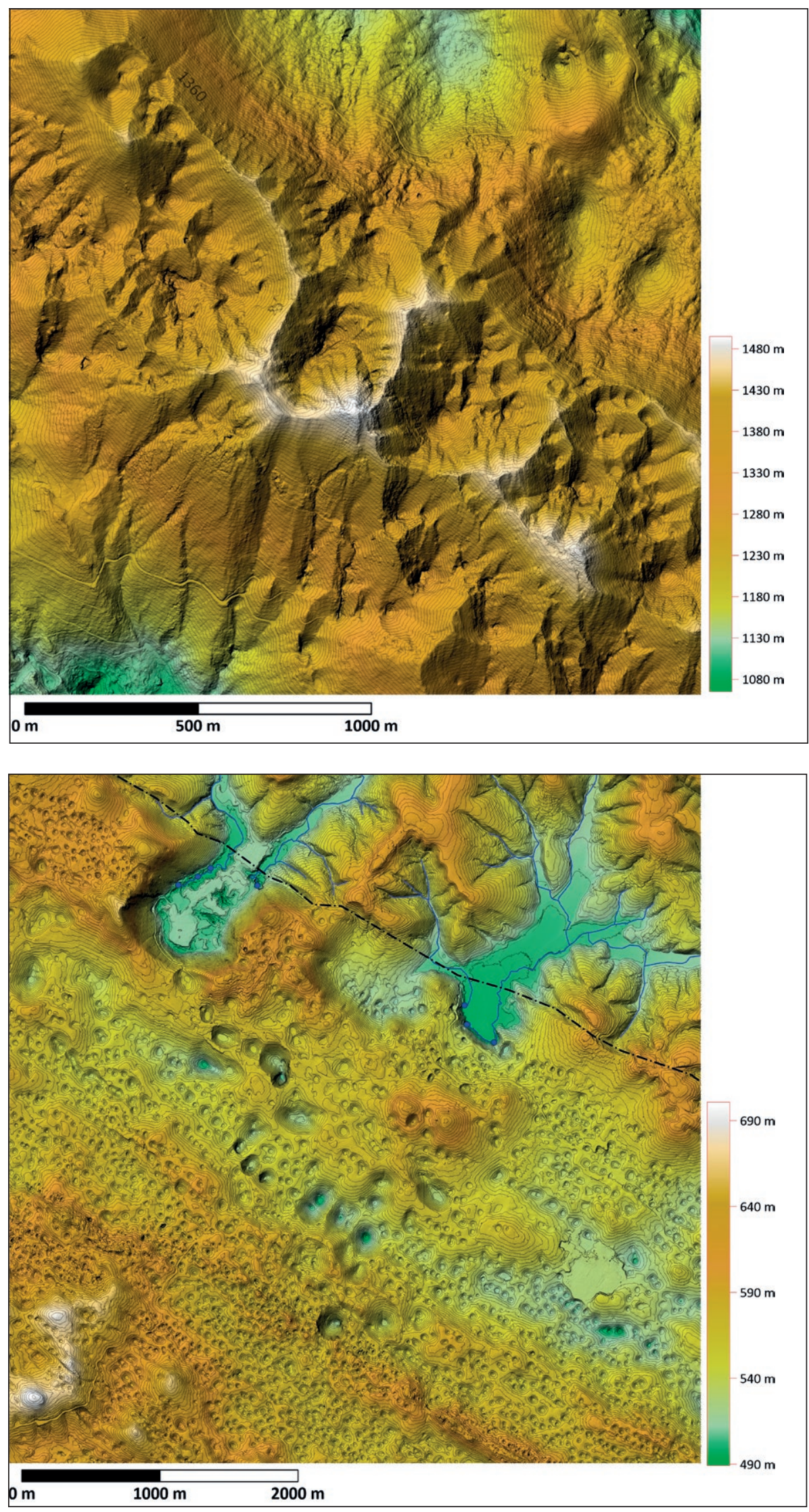

Fig. 21: Dolines of the central part of the Trnovski gozd. At the highest part of the Trnovski gozd, an intertwined network of large dolines was formed in which there are also smaller dolines. It is not clear whether these dolines developed simultaneously or if they belong to different generations. This part of the Trnovski gozd is above the Pleistocene snow line, but there are no significant traces of glaciation on it. The contour interval is $5 \mathrm{~m}$.
Fig. 22: Doline covered surface in the southeastern part of the Podgrajsko podolje. These dolines are arranged into parallel rows that follow the northwest-southeast direction along the strike of the strata. On the massive limestones in the middle of the picture, a group of collapse dolines formed above the caves that drain the water of the ponors in the blind valleys that are in the upper part of the picture. The contour interval is $4 \mathrm{~m}$. 
Trnovski gozd (No. 11 in Fig. 6) is an approximately $25 \mathrm{~km}$ long and up to $10 \mathrm{~km}$ wide karst plateau consisting of several relief units. The plateau lies at altitudes between 800 and $1100 \mathrm{~m}$ with only individual parts reaching higher, up to $1500 \mathrm{~m}$. In the northwest, the plateau is bounded by a dry valley up to $400 \mathrm{~m}$ deep. The southwestern edge of Trnovski gozd represents the thrust edge of Mesozoic rocks to Eocene flysch. In the northwest, where dolomite occurs, the plateau is bounded by deeply incised fluvial valleys. The northwestern part of the plateau surface has remained levelled. In the central part, the original levelled surface is divided into large uvalas with intermediate conical hills. In the northern and northeastern part, the levelled surface rises into a high and narrow ridge which stretches in the NW-SE direction. Several smaller glaciers were formed in the Pleistocene in this part of the Trnovski gozd (Kodelja et al. 2013). Due to the rough relief, the glaciers hardly moved and produced only a few small moraines.

The entire surface of Trnovski gozd is densely covered by solution dolines, which differ considerably in size, shape and distribution. The levelled northwestern part has the densest network of dolines. Their density reaches up to 70 per $\mathrm{km}^{2}$. Most are small measuring from 17 to $88 \mathrm{~m}$ in diameter and are on average $13.5 \mathrm{~m}$ deep. Their share of the surface is $15 \%$.

In the central part, the density of dolines is lower and most of the surface is occupied by large uvalas. Some uvalas are filled with periglacial gravel, while others have dense networks of dolines. Due to the greater slope of the surface, the number of dolines on the intermediate conical hills is smaller.

The dolines are arranged in rows on the high northeastern part of the plateau. The most common doline size in this area is up to a few $100 \mathrm{~m}$ wide and up to $100 \mathrm{~m}$ deep (Fig. 21). There are many dolines up to $1 \mathrm{~km}$ wide in which there are several smaller dolines. In this high part of the plateau, the share of the doline surface is large and in some places the entire surface is covered in dolines. Suffosion dolines are common in uvalas or in larger dolines filled with periglacial gravel or glacial till. There are no collapse dolines in Trnovski gozd.

Podgrajsko podolje (No. 12 in Fig. 6) is a $25 \mathrm{~km}$ long and up to $4 \mathrm{~km}$ wide levelled surface built of Cretaceous and Paleogene limestones and Cretaceous dolomite. The dip of strata is uniform along the entire length of Podgrajsko podolje and is around $30 / 45^{\circ}$. In the northwest, it is bounded below by flysch deposited on Paleogene limestones. The levelled surface is at an altitude of $500 \mathrm{~m}$ in the northwest and raises by about $170 \mathrm{~m}$ in the southeast. In the southwest, Podgrajsko podolje rises in a sharp bend into the karst of Čičarija. There are 17 streams that flow from the flysch, each of which has cre- ated a blind valley where it sinks into the karst. At the edge of these blind valleys there are active water caves, while the rest of the area only contains relict caves. The level of karst water in the Podgrajsko podolje is deeper than $200 \mathrm{~m}$ throughout.

The surface of Podgrajsko podolje is densely covered with solution dolines (Fig. 22). The highest densities are around 400 dolines per $\mathrm{km}^{2}$. The diameters of these dolines are from 21 to $70 \mathrm{~m}$ and the average diameter is $46 \mathrm{~m}$. The share of dolines on the surface varies and depends mainly on the rock. The fewest are on dolomite. The rockiness of the surface also depends on the geological base and is the lowest on dolomite. There is a characteristic distribution of dolines in parallel rows in the northwest-southeast direction, which follows the strike of strata.

In the blind valleys along the northeastern edge of the Podgrajsko podolje, thick layers of allogenic sediments were deposited along the sinkholes of streams covering the otherwise uneven bedrock of the blind valleys. Under current conditions, streams do not deposit sediments but rather erode them and carry them into caves. At the edges of the blind valleys, where the thickness of the alluvium is the smallest, sinks form and eventually turn into suffosion dolines. The deepest suffosion doline was formed in the blind valley of Odolina and is $35 \mathrm{~m}$ deep, measuring $100 \mathrm{~m}$ in diameter.

Several groups of collapse dolines formed in the Podgrajsko podolje. To the northwest of the area, there is a group of collapse dolines, the largest two of which are $450 \mathrm{~m}$ in diameter. These collapse dolines are up to $80 \mathrm{~m}$ deep and their slopes are rounded and only a few smaller collapse dolines have vertical sections in their slopes.

A larger group of collapse dolines formed in an elongated series southeast of the Jezerina blind valley. They measure up to $300 \mathrm{~m}$ in diameter and are up to $60 \mathrm{~m}$ deep. Among them, some have steep and, in some places, rocky slopes. They probably follow the underground flow of the sinking river from the blind valley to the southeast.

Kras (No. 13 in Fig. 6) is a vast $45 \mathrm{~km}$ long and up to $15 \mathrm{~km}$ wide plateau built entirely of Mesozoic and Paleogene carbonate rocks. Most of the plateau is levelled; only in the middle does there stretch a slightly higher belt with conical hills. The levelled surface is also crossed by two dry valleys and a large longitudinal tectonic-generated depression. The surface of the Kras rises from approximately $150 \mathrm{~m}$ above sea level in the northwest up to 450 $\mathrm{m}$ in the southeast.

Kras is a low plateau at the edge of the Gulf of Trieste. It shows Mediterranean climatic influences. Precipitation is approximately $1400 \mathrm{~mm}$, and the drought is pronounced in three summer months. The entire surface of the Kras is without an active surface drainage. In 

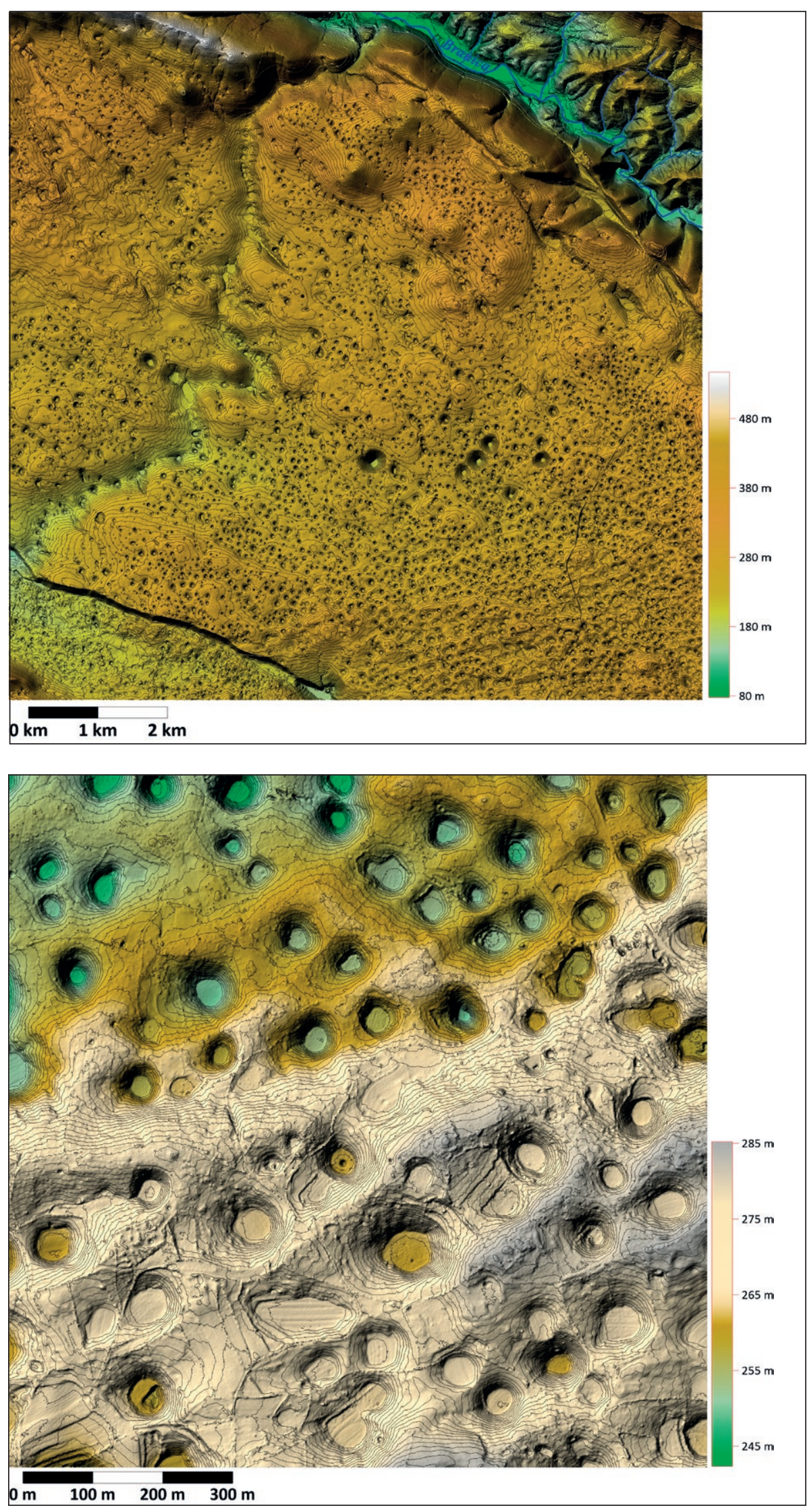

Fig. 23: Central part of the Kras plateau. The levelled surface is divided by a large dry valley, Mali dol, which crosses the plateau from north to south and by a furrow at the Divača fault in the lower part of the picture. In the central part is a group of collapse dolines. Dolines also formed in the dry valley and are bigger than dolines on the plateau. The contour interval is $5 \mathrm{~m}$.
Fig. 24: Dolines on the Lipiški ravnik in the southeastern part of Kras. There is a lot of levelled surface between large dolines, so the density and share of dolines on the surface is relatively small. It is characterized by dolines with steep rocky slopes and anthropogenically flattened bottoms. In some dolines land was dug and used for melioration. The contour interval is $1 \mathrm{~m}$. 
the southeast, the Reka flows from the flysch Brkini and sinks in the Škocjanske jame Cave. The underground flow of the Reka steeply submerges hundreds of metres below the surface after sinking into ponors. The springs are along the coast in the northwestern part of the Kras. The solution dolines in Kras are distributed fairly evenly. There are fewer of them only on limestones with chert, Paleogene limestones and on inclined surfaces. The average number of dolines is 60 per $\mathrm{km}^{2}$ and their share is only $12 \%$ of the surface. There is a lot of levelled surface between the dolines (Fig. 23). Typically, dolines have a steep rocky slope and a large flat bottom, which must be attributed to anthropogenic impacts on dolines (Fig. 24).

Suffosion dolines are rare on Kras. They are found only in allogenic alluvium of the Reka river and alluvium of some smaller sinking rivers in the southeastern part of Kras and at the bottom of some rare solution dolines.

Collapse dolines are a typical and common form on the Kras surface. We can distinguish them into two distinct groups. One group has steep, even vertical slopes covered with screes, and lies above the current active caves that can be reached (Stepišnik 2011). The second group of collapse dolines has gentle slopes and cannot be connected to the current course of the underground river. Apparently they formed when the Reka flowed higher than today through relict tunnels.
The collapse genesis was attributed to 95 dolines on the Kras plateau. Most of the collapse dolines lie in groups that are in a row between the Reka ponors in the Škocjanske jame Cave and the Timava springs along the coast in the northwestern part of Kras. Characteristics of these collapse dolines are large dimensions and an obvious connection to the underground flow of the Reka. This is best seen in the group of collapse dolines above the tunnels of the Škocjanske jame Cave and the Kačna jama Cave (Mihevc 2001), where we can observe the formation of large halls and the formation of collapse dolines in six locations. The largest collapse doline is Globočak, which measures $650 \mathrm{~m}$ in diameter and is $80 \mathrm{~m}$ deep. Its volume is 7 million $\mathrm{m}^{3}$.

The row of collapse dolines then continues to the west past Sežana and Nabrežina. The collapse dolines are up to $500 \mathrm{~m}$ in diameter and up to $100 \mathrm{~m}$ deep. To the north lies another string of collapse dolines approximately in the east-west direction. These collapse dolines are older as evidenced by their gentle slopes and flattened wide bottoms.

Podgorski kras (No. 14 in Fig. 6) is an approximately $10 \mathrm{~km}$ long and up to $4 \mathrm{~km}$ wide levelled surface. It lies between Slavnik in the northeast and the edge of Kras. The levelled surface cuts through the geological structure in such a way that we see alternating bands of Paleocene

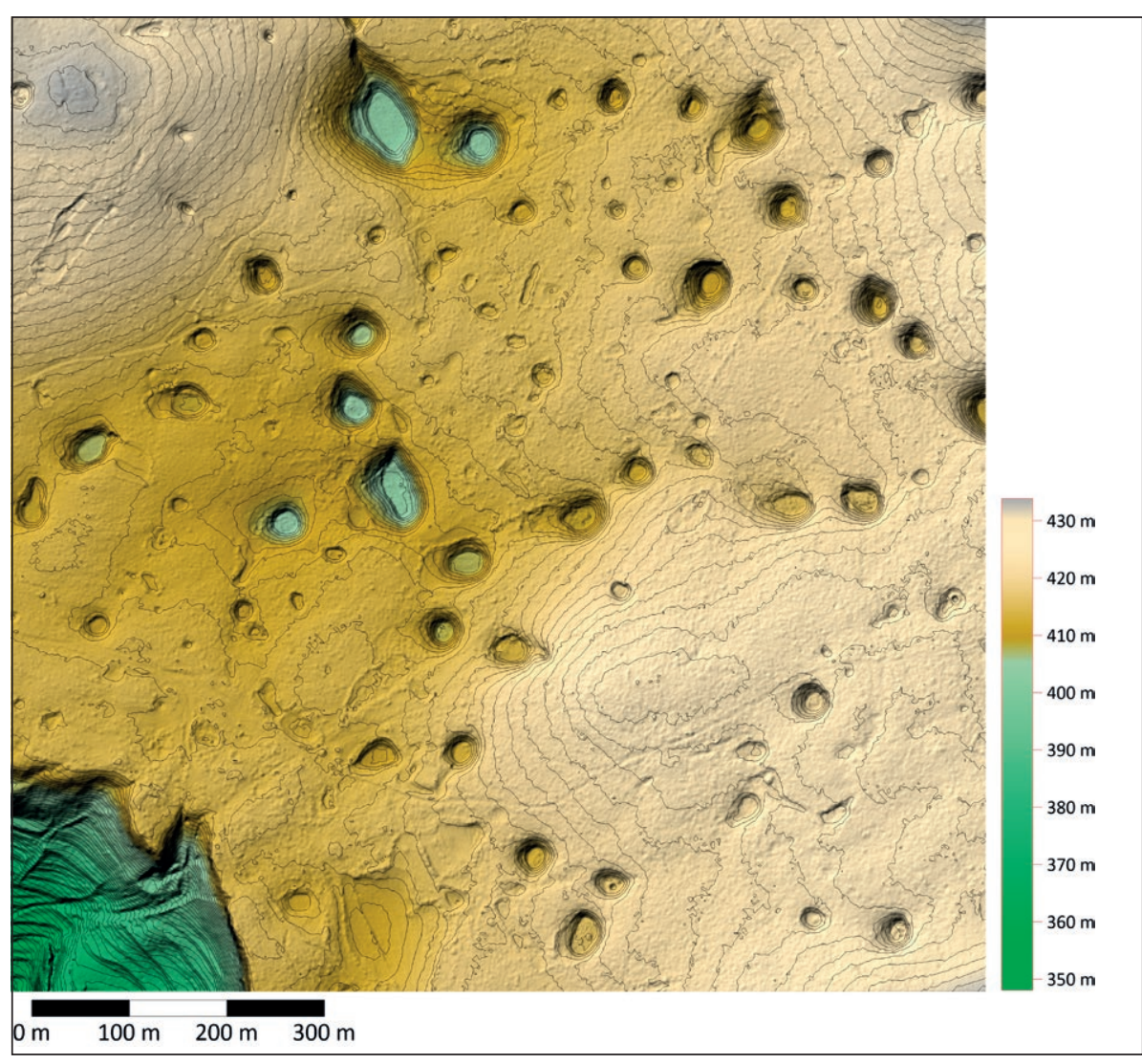

Fig. 25: Typical surface and distribution of dolines on the Podgorski kras. The limestones dip at an angle of about $30^{\circ}$ to the northeast. These dolines are relatively large and shallow with a large flat bottom. The contour interval is $1 \mathrm{~m}$. 
ANDREJ MIHEVC \& ROK MIHEVC

Tab. 2: Doline statistics for selected karst areas.

\begin{tabular}{|c|c|c|c|c|c|c|c|c|c|c|c|c|}
\hline Id & Area & $\mathrm{N}$ & $\begin{array}{c}\text { Doline } \\
\text { area } \\
{\left[\mathrm{km}^{2}\right]}\end{array}$ & $\begin{array}{c}\text { Total } \\
\text { area } \\
{\left[\mathrm{km}^{2}\right]}\end{array}$ & $\begin{array}{c}\text { Mean } \\
\text { doline } \\
\text { area } \\
{\left[\mathrm{m}^{2}\right]}\end{array}$ & $\begin{array}{l}\text { Diame- } \\
\text { ter } 5^{\text {th }} \\
\text { percen- } \\
\text { tile }[\mathrm{m}]\end{array}$ & $\begin{array}{l}\text { Diame- } \\
\text { ter } 95^{\text {th }} \\
\text { percen- } \\
\text { tile }[\mathrm{m}]\end{array}$ & $\begin{array}{l}\text { Mean } \\
\text { diame- } \\
\text { ter [m] }\end{array}$ & $\begin{array}{c}\text { Mean } \\
\text { depth } \\
{[\mathrm{m}]}\end{array}$ & $\begin{array}{c}\text { Mean } \\
\text { slope } \\
{\left[{ }^{\circ}\right]}\end{array}$ & $\begin{array}{c}\text { Doline } \\
\text { density } \\
{[\mathrm{N} /} \\
\left.\mathrm{km}^{2}\right]\end{array}$ & $\begin{array}{c}\text { Relative } \\
\text { doline } \\
\text { area } \\
\text { [\%] }\end{array}$ \\
\hline 1 & Mežakla & 1291 & 2.6 & 9.4 & 1980 & 20.8 & 80.4 & 46.8 & 12 & 9.5 & 137.9 & 27.3 \\
\hline 2 & Pokljuka & 815 & 4.1 & 93.8 & 5020 & 13.2 & 97.7 & 52.2 & 12.5 & 8.2 & 8.7 & 4.4 \\
\hline 3 & Jelovica & 5967 & 15.9 & 48.5 & 2660 & 19.1 & 90.4 & 49.2 & 12.4 & 7.8 & 123.1 & 32.8 \\
\hline 4 & Menina & 1548 & 2.9 & 22.4 & 1860 & 19.4 & 74.9 & 45.1 & 11 & 8.1 & 69.2 & 12.9 \\
\hline 5 & Dobrave & 3417 & 3.5 & 45.8 & 1020 & 14.2 & 54.4 & 33.9 & 3.9 & 2.5 & 74.6 & 7.6 \\
\hline 6 & Hrastovec & 266 & 0.4 & 6.4 & 1510 & 18.1 & 68.2 & 41 & 7.5 & 6.4 & 41.3 & 6.2 \\
\hline 7 & $\begin{array}{l}\text { Kočevsko Ribniško } \\
\text { polje }\end{array}$ & 13630 & 13.9 & 49.4 & 1020 & 16.4 & 50.7 & 34.3 & 5.1 & 1.9 & 276 & 28.1 \\
\hline 8 & Bela krajina & 38184 & 57.9 & 261.6 & 1520 & 21 & 62.4 & 42.1 & 6.7 & 3.4 & 146 & 22.1 \\
\hline 9 & Logaški ravnik & 7325 & 10.5 & 30.1 & 1430 & 21.8 & 59.4 & 40 & 7.2 & 2.5 & 243.3 & 34.8 \\
\hline 10 & Hrušica & 11101 & 16.1 & 79.8 & 1450 & 17.3 & 66.8 & 39.9 & 10.3 & 8.3 & 139.1 & 20.2 \\
\hline 11 & Trnovski gozd & 13376 & 28.4 & 191.1 & 2120 & 17.5 & 88.1 & 46.1 & 13.5 & 8.1 & 70 & 14.9 \\
\hline 12 & Podgrajsko podolje & 13341 & 23.7 & 97.4 & 1780 & 20.8 & 69.7 & 43.6 & 9.1 & 4.4 & 136.9 & 24.4 \\
\hline 13 & Kras & 32817 & 63.3 & 544.6 & 1930 & 14.4 & 79.1 & 42.6 & 7.2 & 3.1 & 60.3 & 11.6 \\
\hline 14 & Podgorski kras & 2050 & 2.8 & 39.3 & 1360 & 15.3 & 61.7 & 38.3 & 5.7 & 3.6 & 52.1 & 7.1 \\
\hline 15 & Banjšice & 4647 & 9.4 & 45.9 & 2030 & 19.1 & 81.4 & 46.7 & 12.1 & 7.9 & 101.1 & 20.5 \\
\hline 16 & Dobrovlje & 2107 & 5 & 29.7 & 2370 & 22.1 & 86.3 & 50.8 & 14.9 & 10.6 & 71 & 16.8 \\
\hline 17 & Hotenjski ravnik & 5546 & 6.4 & 18 & 1150 & 19.9 & 53.5 & 36.8 & 7.3 & 3.6 & 308 & 35.3 \\
\hline 18 & Javorniki & 6743 & 9.6 & 172.4 & 1430 & 16.9 & 61.7 & 39.7 & 9.3 & 7.4 & 39.1 & 5.6 \\
\hline 19 & Nanos & 4211 & 6.6 & 71.8 & 1580 & 14.8 & 69.5 & 40.1 & 10.2 & 8 & 58.7 & 9.3 \\
\hline 20 & Postojnski kras & 4402 & 5.8 & 28.9 & 1330 & 17.6 & 56.6 & 38 & 8.5 & 5.4 & 152.1 & 20.2 \\
\hline 21 & Šentviška planota & 711 & 1.5 & 22.2 & 2050 & 16.7 & 78.5 & 46.8 & 10.7 & 7.3 & 32.1 & 6.6 \\
\hline 22 & Snežnik & 11920 & 28.6 & 264.8 & 2400 & 19.1 & 89.4 & 47.2 & 12.6 & 7.6 & 45 & 10.8 \\
\hline 23 & Trnovski gozd SZ & 4711 & 6.3 & 28.8 & 1340 & 17.4 & 59.3 & 38.8 & 8.9 & 5 & 163.7 & 21.9 \\
\hline 24 & Trnovski gozd JV & 8662 & 22.1 & 162.3 & 2550 & 17.8 & 100.5 & 50.1 & 16 & 9.1 & 53.4 & 13.6 \\
\hline 25 & Velika planina & 501 & 1 & 9 & 2080 & 15.8 & 80.8 & 46.5 & 12.8 & 8.9 & 55.6 & 11.6 \\
\hline 26 & Zasavje & 897 & 2.2 & 8.6 & 2470 & 25 & 89.5 & 52.6 & 11.8 & 7.8 & 103.8 & 25.6 \\
\hline
\end{tabular}


limestone with thin layers of the Eocene flysch on the surface. The surface on the limestone is levelled and covered with sparse dolines and on the flysch surface shallow river valleys with sinkholes have formed. There are several caves on the levelled surface reaching a depth of up to $200 \mathrm{~m}$. The springs are below the edge of the karst at an altitude of between 40 and $70 \mathrm{~m}$. The plateau lies only about $10 \mathrm{~km}$ from the sea, so it is strongly influenced by the Mediterranean climate.

The surface of the Podgorski kras is levelled at an altitude of 440 to $500 \mathrm{~m}$. The density of dolines on the surface is small, reaching only a few tens of dolines per $\mathrm{km}^{2}$. The share of dolines on the levelled surface is small as it is only $7 \%$. The dolines, which are of corrosion origin, are small and shallow and have a flat bottom which is a consequence of the use of the dolines for agriculture (Fig. 25). There are no suffosion dolines or collapse dolines on the Podgorski kras.

A special feature of the area is the large number of large unroofed caves exposed on the surface. These are well visible in the Črnotiče quarry at the edge of the Podgorski kras.

\section{DOLINE STATISTICS}

Table 2 presents statistical results of the dolines per stud- ied karst area (Fig. 6) as well as from the areas which were not described in the details.

With the study, we detected 471,192 dolines, which represent three genetic types. The density of dolines on levelled surfaces can be as high as 500 per $\mathrm{km}^{2}$. They are missing on the bottoms of poljes and steeper slopes and are less abundant on inclined surfaces.

Most abundant $(470,325)$ are solution dolines. The study revealed that the average doline is $9 \mathrm{~m}$ deep, has a diameter of $42 \mathrm{~m}$ and a volume of $14,098 \mathrm{~m}^{3}$.

Collapse dolines are formed by locally enhanced dissolution of limestone due to specific types of fracturisation of rock, concentrated underground flow routes, and large oscillations of groundwater. We have designated 314 dolines to be of collapse origin. The mean depth of collapse dolines is $49 \mathrm{~m}$, and 20 of them are deeper than $100 \mathrm{~m}$. The mean volume is 1.2 million $\mathrm{m}^{3}$, with the largest having a volume of 11.6 million $\mathrm{m}^{3}$. Most of the collapse dolines can be found close to ponors or springs or corridors where large underground rivers flow.

Alluvial dolines are formed by suffosion of sediments deposited on the karst surface to the underground, forming funnel-like depressions. As the sediments are mostly deposited in blind valleys or on poljes, most of these 553 features are located in such environments.

\section{CONCLUSIONS}

The analysis of the relief of Slovenia with the help of lidar data shows the number, distribution and shape of the dolines, which are the most common karst relief form. The distribution of dolines can also help to infer their origin. This applies to all genetic types of dolines - collapse, suffosion and solution dolines.

Collapse dolines are mostly distributed on a levelled karst surface above the flows of underground rivers. They are formed as a result of corrosion where the underground rivers cross fissured zones. They are old relief forms that develop along with the formation of caves and the surface. They are a characteristic form of the Dinaric karst, but are missing on the high karst plateaus and in the Alpine karst.

Suffosion dolines are the result of the piping of Pleistocene sediments from the surface into the underlying karst cavities. In the Alpine region, they formed in moraine or periglacial material after the last glacial maximum. In the Dinaric karst, where these dolines are the most numerous compared to the Alpine and isolated karst, they are mainly related to allogenic sediments of the contact karst and to the sediments at the bottom of the karst poljes.
Most of them form as a sudden sink with steep walls and then eventually slowly turn into funnel-shaped dolines. In the karst poljes, suffosion dolines are formed due to fluctuations in the karst water level, even when the water level rises during floods. In most of the Dinaric karst, where the surface is highly rocky and the soil cover is not continuous, suffosion dolines and sinks are absent.

Solution dolines are the most common doline type in Slovenia and are formed on all carbonate rocks and on young conglomerates wherever there is effective vertical drainage into the karst and no surface water flow. An important factor influencing the location of dolines is the slope of the surface. There are fewer dolines on slightly sloped surfaces, but they are completely absent on steep slopes, even though there is also karst water flow there. Above the slope of $20^{\circ}$, dolines are almost absent. Ninetynine percent of the dolines in Slovenia are located on a surface with an inclination below $20^{\circ}$.

Each solution doline represents its own zone of deepening, followed by slope processes. In the resulting hollows, processes are triggered that either accelerate or inhibit the growth of the depressions. At the bottom of 
the depression, some surface water is concentrated and thus enhances corrosion. Additionally, soil accumulates at the bottom of the depressions, which accelerates biological activity and $\mathrm{CO}_{2}$ production in the subcutaneous zone. This accelerates the growth of depression. Inhibitory processes are also triggered. Gravel and rocks from the slopes of the doline also accumulate in the bottom. Further deepening of the bedrock ground of the dolines is possible only when they dissolve. The existence of networks of equal size solution dolines on karst surfaces indicates that the formation and growth of dolines over a longer period of time is mainly governed by surface factors. Namely, if the dolines were determined by the aggregation of water in the subcutaneous zone, there would be competition and takeover of the water flow between trickles of percolating water, which could result in uneven growth of the dolines. Therefore, much larger dolines would form among equally large dolines as well as very small ones. This is not the case and we see groups of dolines of about the same size formed.

The solution dolines are mostly concentric depressions, rounded, bowl-shaped in cross-section and are very stable relief forms that reach equilibrium. Various tectonic structures such as faults and cracks do not have a significant effect on the shape of solution dolines. Only dip direction somewhat influences the doline distribution so the concordant slopes of the dolines are less steep. Geological structures are necessary, but are present everywhere, so other surface factors and processes are maintaining the circular and funnel-shaped form.

The spatial distribution of the solution dolines shows different patterns. On the plains along the karst poljes and the younger still fairly flat plains, the dolines are distributed mostly randomly and are approximately the same size. There is still some flat surface between the dolines. Attachment of dolines to faults or dip of strata is not pronounced. On older levelled surfaces, the variability of doline size is greater and there is also a greater relation to geological structures. The dolines there are also of various sizes. The dolines do not join together into larger dolines or transform to poljes or uvalas.

The size of solution dolines varies from a few metres to over one kilometre in diameter. They can be up to a hundred metres deep. The average size of the dolines is $42 \mathrm{~m}$ in diameter and $9 \mathrm{~m}$ deep. The different size of the dolines indicates that they began to develop at different times or that we have several generations of dolines in the karst. The largest dolines are found in the Alpine karst in Pokljuka and Jelovica as well as in the Dinaric karst and the Trnovski gozd.

The age of the solution dolines cannot be determined precisely. The dolines form in places where corrosion is slightly stronger than the general surface corrosion of the neighbourhood. We estimate the denudation rate in Slovenia is between 10 and $50 \mathrm{~m}$ per million years (Mihevc 2001). The dolines, when formed, became part of the karst surface and are lowering at about the same rate. Therefore, only the minimum age of an individual doline can be determined.

Dating networks of dolines sometimes allows for maximum age dating. In Jelovica, Mežakla and Trnovski gozd, the dolines touch each other and occupy most of the surface. These surfaces experienced a general uplift 2-3 million years ago and developed dolines at the same time. The same is with Kočevsko Ribniško polje, Bela krajina and Logaški ravnik, where doline growth starts with tectonic displacements that cause the lowering of groundwater.

\section{REFERENCES}

Bárány-Kevei, I., 1998: Connection between morphology and ecological factors of karst dolines (Aggtelek Hills, Hungary).- Supplementi di Geografia Fisica e Dinamica Quaternaria, III, 4, 115-119.

Bavec, M. \& T. Verbič, 2004: The Extent of Quaternary Glaciations in Slovenia.- Developments in Quaternary Science, 2, pp. 385-388. http://dx.doi. org/10.1016/S1571-0866(04)80088-5

Cramer, H., 1941: Die Systematik der Karstdolinen.Neues Jahrbuch für Mineralogie, Geologie und Paleontologie, Beilage-Band, Abst. B 85, 293-382.

FVG, 2021: Lidar scan of Trieste region.- [On- line] Available from: http://irdat.regione.fvg. it/CTRN/ricerca-cartografia/caricaElementi. jsp? what $=$ Comune\&item $=$ MONRUPINO $\quad[$ Accessed $11^{\text {th }}$ May 2021].

Cvijić, J., 1893: Das Karstphänomen. Versuch einer morphologischen Monographie.- Geographische Abhandlungen, Band 5, Heft 3, E. Hölzel, pp.113, Wien.

Čar, J., 2001: Structural bases for shaping of dolines.Acta carsologica, 30, 2, 239-256.

Ford, D.C. \& P.W. Williams, 1989: Karst geomorphology and hydrology.- Unwin Hyman, 601 pp., London.

Frelih, M., 2014: Gostota, razporeditev in morfološke 
značilnosti vrtač na izbranih primerih v Sloveniji.PhD thesis, Univerza v Ljubljani, Filozofska fakulteta, pp. 238.

Gabrovšek, F. \& U. Stepišnik, 2011: On the formation of collapse dolines: A modelling perspective.- Geomorphology, 134, 23-31. https://doi.org/10.1016/j. geomorph.2011.06.007

Gams, I., 1974: Kras: Zgodovinski, naravoslovni in geografski oris.- Slovenska matica, pp. 359, Ljubljana.

Gams, I., 2003: Kras v Sloveniji v prostoru in času.Založba ZRC, pp. 516, Ljubljana.

Geološki zavod Slovenije, 2021: Basic geological map of Slovenia 1:100.000.- [Online] Available from: https://ogk100.geo-zs.si/ [Accessed $11^{\text {th }}$ May 2021]

Gostinčar, P., 2016: Geomorphological characteristics of karst on contact between limestone and dolomite in Slovenia.- PhD thesis. University of Nova Gorica, pp. 276.

Grlj, A., 2020: Omejevanje kraških kotanj $\mathrm{z}$ analizo polrezov.- Dela, 53, 5-22. https://doi.org/10.4312/ dela.53.5-22

Grund, A., 1914: Der geographische Zyklus im Karst.Zeitschrift der Gesellschaft für Erdkunde zu Berlin, 8, 621-640.

Habič, P., 1969: Hidrografska rajonizacija krasa v Sloveniji.- Krš Jugoslavije, 6, 79-91.

Häuselmann, P., Mihevc, A. \& M. Fiebig, 2015a: Age of the allogenic quartz pebbles from Snežna jama, Huda luknja and Špehovka for implication of tectonic uplift Kamnik Alps and Karavanke, Slovenia.In: Mitrovic, I. \& L. Plan (eds) Workshop Advances in Active Tectonics and Speleotectonics - Book of Abstracts, $20^{\text {th }}-24^{\text {th }}$ September 2015, Vienna. Natural History Museum Vienna \& University of Vienna, 24, Vienna.

Häuselmann, P., Mihevc, A., Pruner, P., Horáček, I., Čermák, S., Hercman, H., Sahy, D., Fiebig, M., Zupan Hajna, N. \& P. Bosák, 2015b: Snežna jama (Slovenia): Interdisciplinary dating of cave sediments and implication for landscape evolution.- Geomorphology 247, 10-24. https://doi.org/10.1016/j.geomorph.2014.12.034

Kodelja, B., Žebre, M. \& U. Stepišnik, 2013: Poledenitev Trnovskega gozda.- E-GeograFF, 6 Znanstvena založba Filozofske fakultete Univerze v Ljubljani, Ljubljana.

Kraus, F., 1887: Über dolinen.- Verhandlungen der kaiserlich-königlichen geologischen Reichsanstalt, 54-62.

Mihevc, A., 2001: Speleogeneza Divaškega krasa.- Zbirka ZRC, 27, Založba ZRC, pp. 180, Ljubljana.

Mihevc, A., 2011: Evolution of dolines from caves: a case study from Kras Plateau, Western Slovenia.- Car- bonate geochemistry: reactions and processes in aquifers and reservoirs, $6^{\text {th }}-9^{\text {th }}$ August 2011, Billings, Montana. Karst Water Institute, 56-59, Leesburg (Virginia).

Mihevc, A., Horáček, I., Pruner, P., Zupan Hajna, N., Čermák, S., Wagner, J. \& P. Bosák, 2013: Miocene Pliocene age of cave Snežna jama na Raduhi, Southern Alps, Slovenia.- In: Filippi, M. \& P. Bosák (eds.) 16th International Congress of Speleology, $21^{\text {st }}-28^{\text {th }}$ July 2013, Brno. International Union of Speleology: Czech Speleological Society, 379-383, Brno.

Mihevc, A., Bavec, M., Häuselmann, P. \& M. Fiebig, 2015: Dating of the Udin Boršt conglomerate terrace and implication for tectonic uplift in the northwesthern part of the Ljubljana Basin (Slovenia).- Acta carsologica, 44, 2, 169-176. https://doi.org/10.3986/ ac.v44i2.2033

Mihevc, A. \& R. Mihevc, 2021: Map of Slovenian dolines.- [Online] Available from: https://dolines.org/ [Accessed May 11 $1^{\text {th }} 2021$ ].

Mihevc, A. \& N. Zupan Hajna, 1996: Clastic sediments from dolines and caves found during the construction of the motorway near Divača, on the classical Karst.- Acta carsologica, 25, 169-191.

Placer, L., 1981: Geološka zgradba jugozahodne Slovenije.- Geologija, 24,1, 27-60.

Placer, L., 1998: Contribution to the macrotectonic subdivision of the border region between Southern Alps and External Dinarides.- Geologija, 41, 223-255.

Putick, W., 1889: Die Katavotros im Kesselthale von Planina in Krain.- Wochenschrift des Österreichischen Ingenieur- und Architekten - Vereines, Nr. 46 und 47 .

Ronneberger, O., Fischer, Ph. \& T. Brox, 2015: U-Net: Convolutional Networks for Biomedical Image Segmentation.- MICCAI, 234-241.

Schmidl, A., 1854: Die Grotten und Höhlen von Adelsberg, Lueg, Planina und Laas.- Braumüller, pp. 316, Wien.

Stepišnik, U., 2010: Udornice v Sloveniji.- Znanstvena založba Filozofske fakultete, pp. 118, Ljubljana.

Stepišnik, U., 2011: Sediments in collapse dolines on the Kras plateau, Slovenia.- Acta geographica Slovenica, 51, 2, 233-252. https://doi.org/10.3986/AGS51201

Stepišnik, U., 2015: Are solution dolines formed by solution?- Dela, 43, 29-40. https://doi.org/10.4312/ dela.43.29-40.

Sweeting, M.M., 1973: Karst Landforms.- Columbia University Press, pp. 362, New York.

Šifrer, M., 1969: Kvartarni razvoj Dobrav na Gorenjskem.- Geografski zbornik, 11, 101-221.

Šušteršič, F., 1984: Metoda morfometrije in računalniške obdelave vrtač.- Acta carsologica, 13, 79-98. 
Šušteršičč, F., 1994: Classic dolines of classical site.- Acta carsologica, 23, 123-154.

Triglav Čekada, M. \& V. Bric, 2015: Končan je projekt laserskega skeniranja Slovenije.- Geodetski vestnik, 59-3, 586-592.

Turk, J., Bonacci, O., Gabrovšek, F., Žele, A. \& W. Tuttle, 2010: Dinamika podzemne vode v kraškem zaledju izvirov Ljubljanice.- Carsologica, 11, Založba ZRC, pp. 136, Ljubljana.

Zambo, L. \& D.C. Ford, 1997: Limestone dissolution processes in Beke doline Aggtelek national park, Hungary.- Earth Surface Processes and Landforms, 22, 531-543.
Zupan Hajna, N., Mihevc, A., Pruner, P. \& P. Bosák, 2008: Palaeomagnetism and magnetostratigraphy of Karst sediments in Slovenia.- Carsologica, 8, Založba ZRC, pp. 266, Ljubljana.

Žebre, M., Stepišnik, U., Colucci, R.R., Forte, E. \& G. Monegato, 2016: Evolution of a karst polje influenced by glaciation: the Gomance piedmont polje (northern Dinaric Alps).- Geomorphology, 257, 143-154. https://doi.org/10.1016/j.geomorph.2016.01.005 